\title{
الوجوه والنظائر وتحليلها في الأسماء
}

Hasril A. Ruhing, Sriwahyuningsih R. Saleh, Islahiddin Sastra Arab, Fakultas Ilmu Budaya - UMG

$$
\text { تجريد البحث }
$$

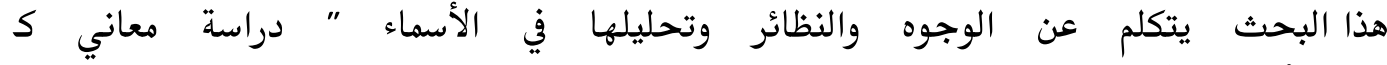

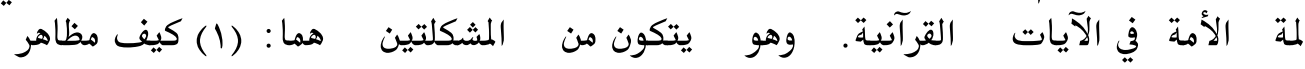

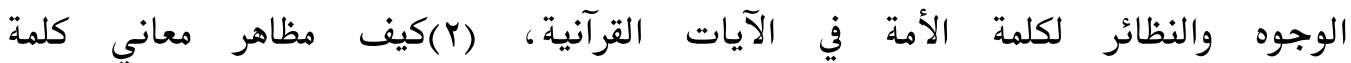

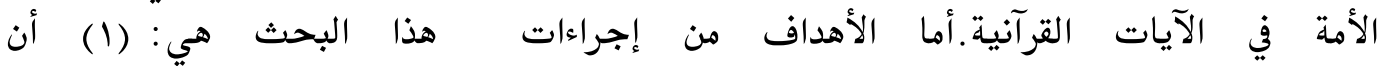

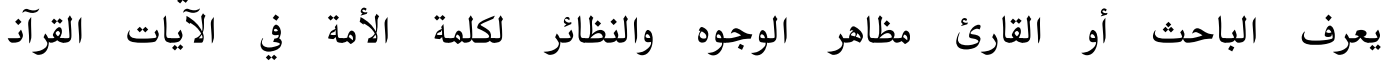

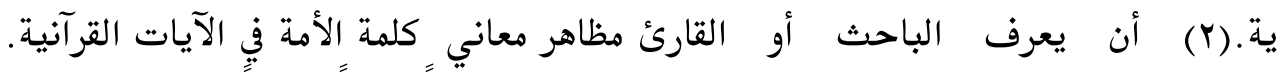

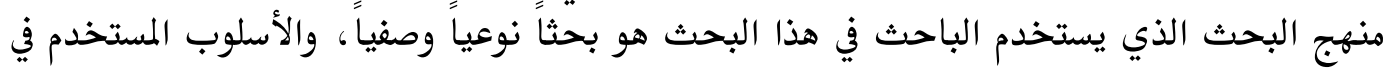

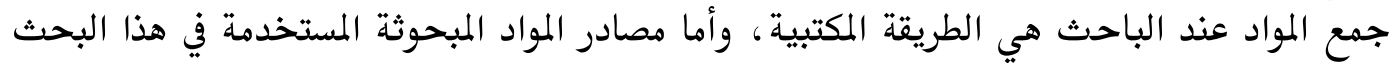

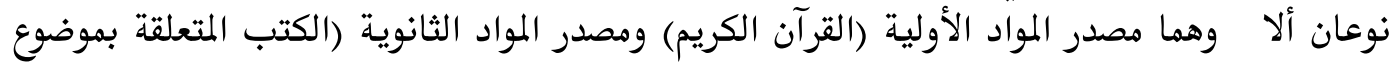

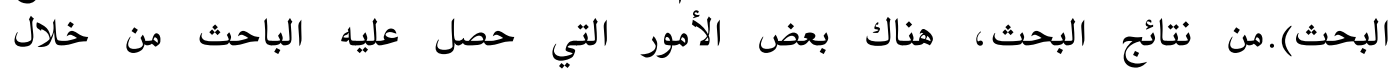

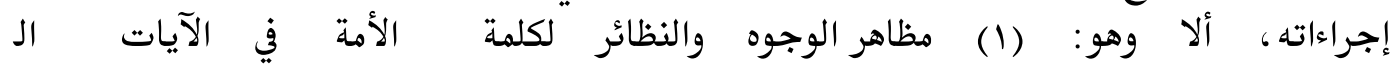

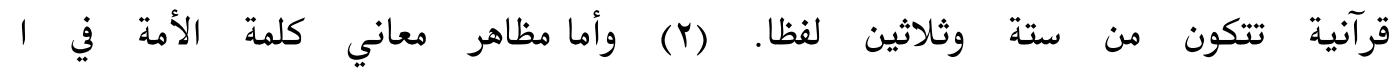

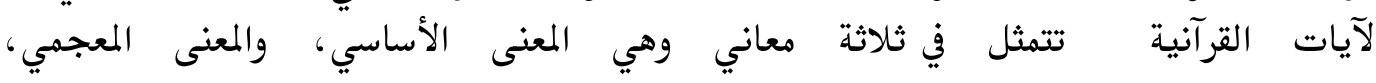
والمعنى السياقي.

الكلمات الرئيسية: مظاهر الوجوه والنظائر، كلمة الأمة، معاني كلمة الأمة. أ. ألمقدمة

إن اللغة العربية هي أغنى اللغات في تعدد المفردات الدالة على معنى واحد من ناحية، وكما عرفت أيضا بجمال القرآن اللغوي، تلك الظاهرة العجيبة التي امتاز بها القرآن في وصف حروفه وترتيب كلماته ترتيبا دونه كل ترتيب تعاطاه الناس في كلامهم ولقد وصل هذا الجمال اللغوي إلى قمة الإعزاز، بحيث لو دخل في القرآن شئ من كلام الناس لاختل مذاقه في أفواه قارئه واختل نظامه في آذان سامعيه، ومن عجيبه كثير من النواحي.اوكما

\section{'A Jamiy, Jurnal Bahasa dan Sastra Arab} Volume 07, No. 1,Juni 2018 
أن اللغة العربية تنشأ في أول مرة نشأتان: نشأة حينما أخذ الإنسان يلفظ أصواتا مراكبة ذات مقاطع وكلمات متميزة لتعبير عما يجول بخاطره من معان وما يحسه من مدركات، ونشأة حينما

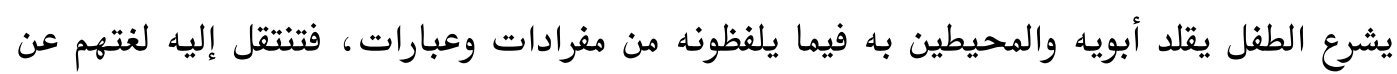
هذا الطريق. واللغة عند اللغويين تعريفات منها كما ورد في ق قول ابن جني : قال: اللغة أصوات يعبر بها كل قوم عن أغراضهم.ب وأما دسوسر فقال اللغة هي نظام رموز صوتي

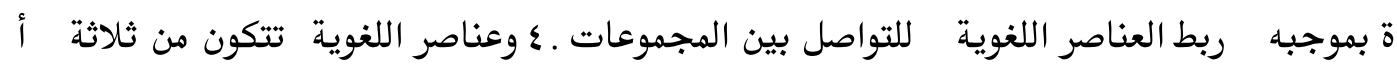
قسام:0الأصوات، والمفردات، والتراكيب. والآخر تنقسم اللغة إلى اسم، فعل، وحرف في بحث الكلام. والاسم ما دل على معنى في نفسه غير مقترن بزمان : كخالد وفرس وعصفور ودار وحنطة وماء، والفعل هو: ما دل على معنى في نفسه مقترن بزمان كجاء ويجيئ. والحرف هو: ما دل على في معنى في غيره، مثل : هل، وفي، ولم، وعلى وإن، ومن.

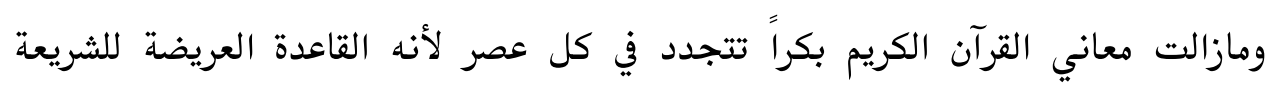
الإسلامية الصالحة لكل زمان ومكان. ولما كانت معاني هذا القرآن مكنونة في ألفاظه العربية المعجزة تنوعت مسالك العلماء في استخراج معانيه من هذه الألفاظ، وقامت دراسات حول ألفاظه العربية

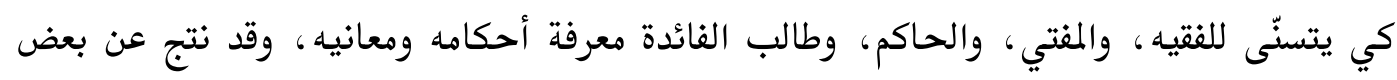
هذه الدراسات ما يسمى بالوجوه والذظائر في القرآن الكريم التي كشف النقاب عن المعاني المتعددة والمتجددة التي يصلح أن يدل عليها اللفظ الواحد، وكذلك المعنى الواحد الذي يصلح أن تدل عليه ألفاظ متعددة وهذا يدل على اتساع قاعدة الشريعة الإسلامية كي تصلح لعلاج الحياة البشرية في كل

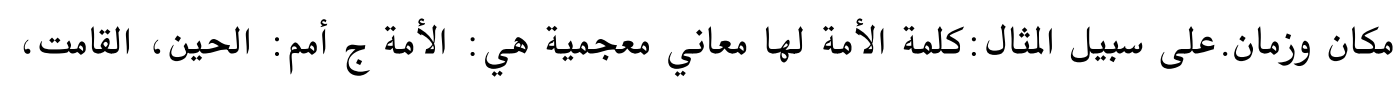

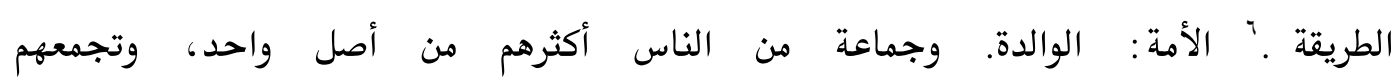

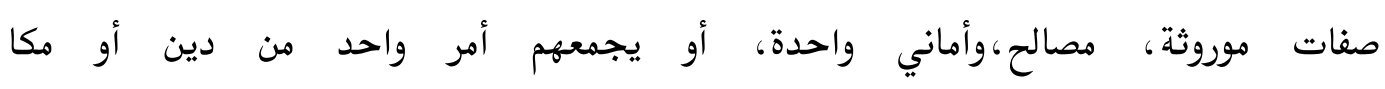

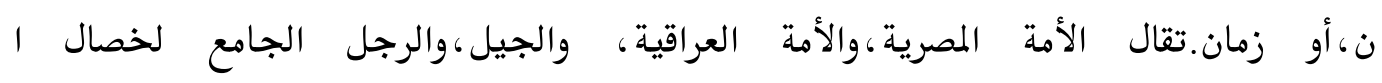

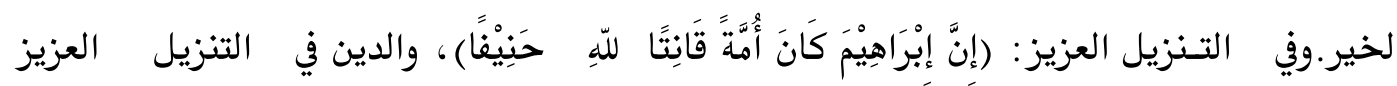

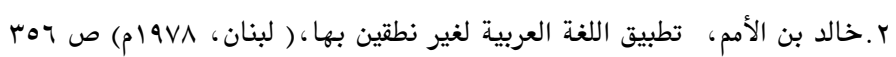

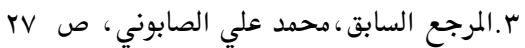

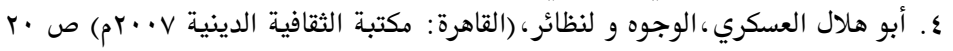

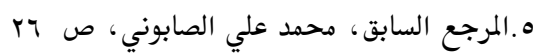

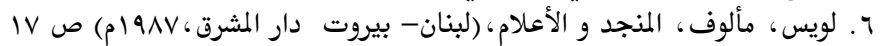

\section{'A Jamiy, Jurnal Bahasa dan Sastra Arab \\ Volume 07, No. 1,Juni 2018}




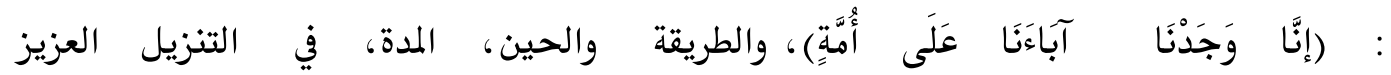

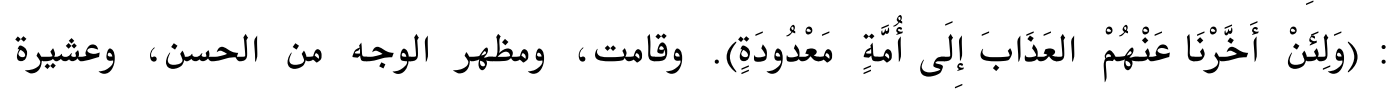

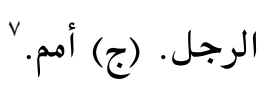

علم الوجوه والنظائر من العلوم القرآنية تتصدّى لتفسير ألفاظ آيات الذكر الحكيم

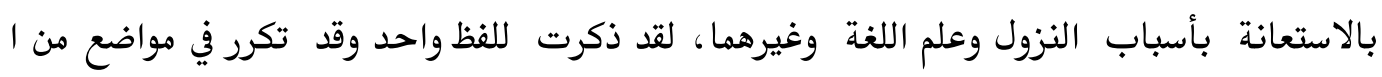
لقرآن الكريم معان شتى سميت بالوجوه، وهذه الوجوه تشتمل على مصاديق خاصة تارة أو معان

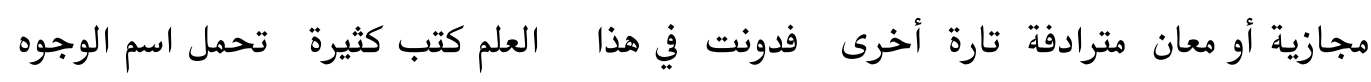

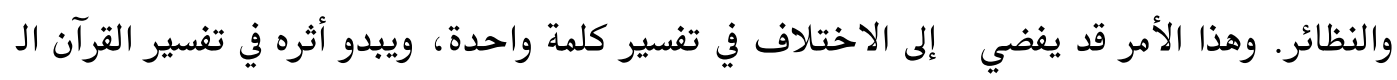
كريم.

فمن هنا جاءت ضرورة التعرض لدراسة حول المصنفات في هذا العلم ومسالكها في تفسير

الألفاظ القرآنية.

علم الوجوه والنظائر، فرع من فروع علم التفسير، وهو علم يبحث في كل لفظ في القرآن

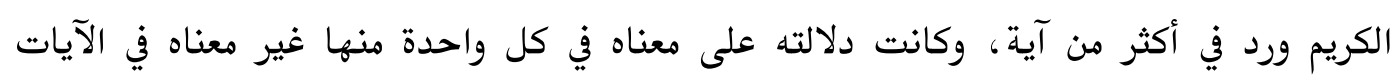

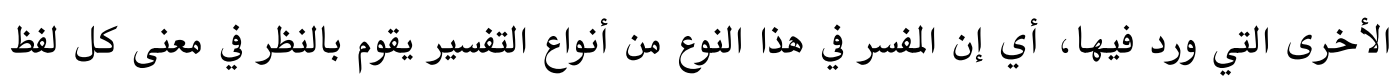

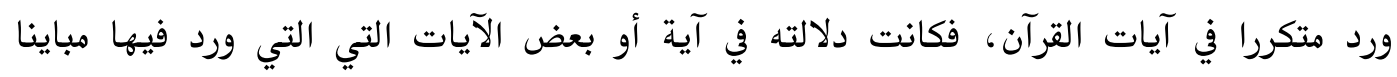

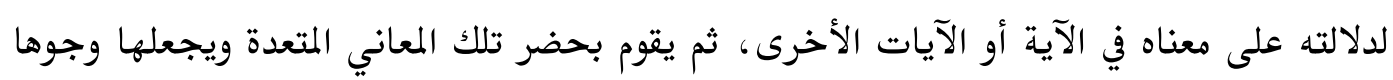
للفظ.

في القرآن الكريم كلمة أمة تذكر في إثنتين وخمسين مرة في أربع وعشرين سورة،

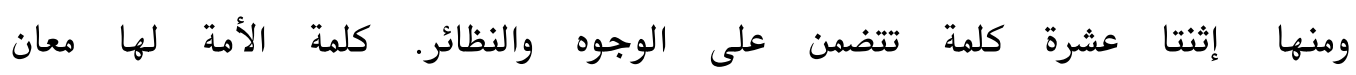

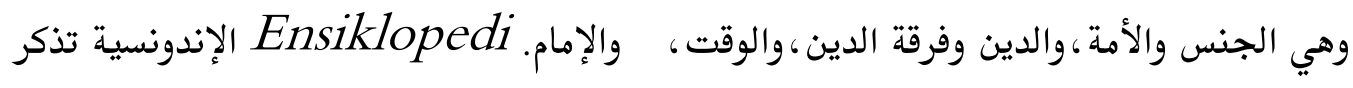

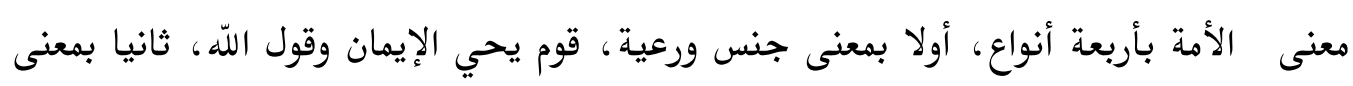

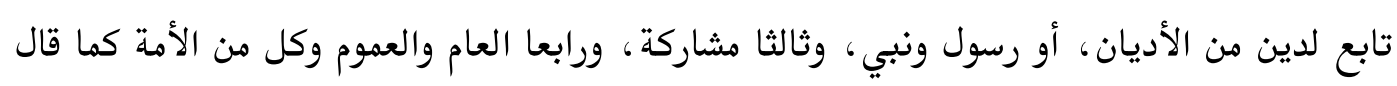

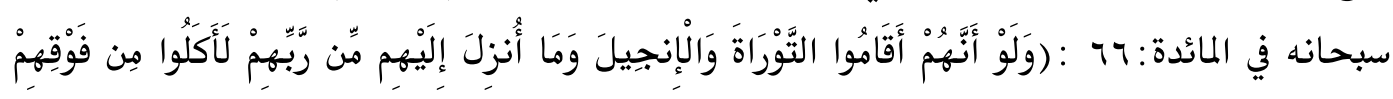

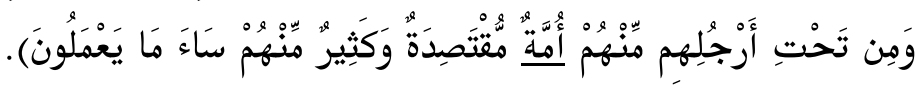

\section{'A Jamiy, Jurnal Bahasa dan Sastra Arab Volume 07, No. 1,Juni 2018}


أي منهم جماعة معتدلة مستقيمة غير غالية ولا مقصورة، وهم الذين آمنوا بمحمد صلى اللّه عليه وسلم كعبد الله بن السلام والذجاشي وسلمان.^

ب. البحوث ا. أ. الوجائق الوجوه والنظائر أ.) تعريف الوجوه والنظائر

كما ورد في أقوال علماء اللغة كأبي عبيد القاسم ابن سلام، وهو عرف الوجوه

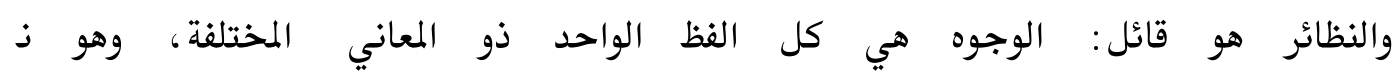

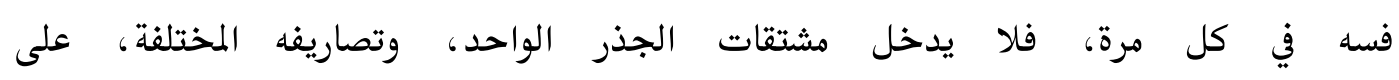
هذا الذحو: كلمة الصواب جاءت بمعنى طوير يكون بالحجاز، أبلق ، وجاءت بمعنى الاقتراح، فجاءت بمعنى نقيض الخطأ. كما جاء في حديث أبي درداء: لا تفقه حتى ترى للقرآن وجوها أي ترى له معاني يحتملها، فتهاب الإقدام عليه. وأما النظائر هي وحدة اللفظ في المواضع المتعددة، أو

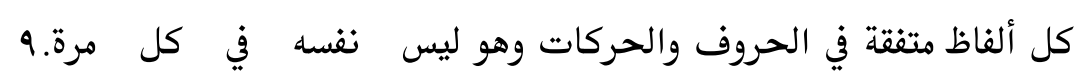
وأما ورد في قول محمد شيماء محيي العوادي: الوجوه والنظائر هي أن تكون اللفظة واحدة

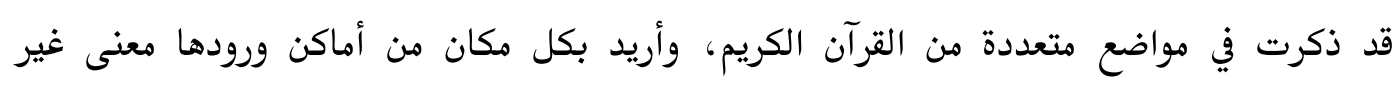
معناها في المواضع الأخرى، فهذه الوجوه والذظائر. فوحدة اللفظ في المواضع المتعددة هي الذظائر، ودلالة كل لفظة على معنى مستقل، أو على غير معانيها في المواضع الأخرى هي الوجوه، أي النظائر يشير به إلى الكلمة في تكراتها في مواضع متعددة في القرآن الكريم، فقيل: النظائر اسم للأفاظ، والوجوه اسم للمعاني هذه الألفاظ. ·1 (والوجوه والنظائر) مصطلح خاص بألفاظ القرآن الكريم المشتركة، يقابله (المشترك اللفظي) مصطلح عام يطلق على اتفاق اللفظ واختلاف المعنى، إذا تكون اللفظة محتملة معنيين أو أكثر. وينبغي أن يكون تعدد المعنى على نحو من الاتفاق بين المتكلمين لهذه اللغة، أو تلك، فقيل فيه (اللفظ الواحد الدال على معنيين مختلفين فأكثر دلالة على السواء عند أهل تلك اللغة).

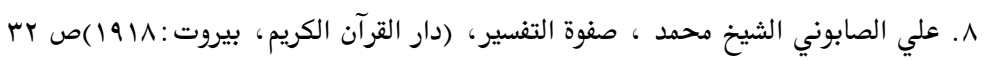

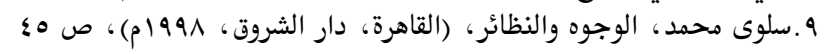

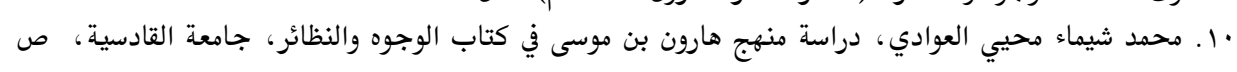

\section{'A Jamiy, Jurnal Bahasa dan Sastra Arab Volume 07, No. 1,Juni 2018}


وينبغي أيضا أن يظل المعنيان مستعملان في إطار هذه اللغة لا يغلب المعنى معنى الآخر، وهذا ما يفهم من كلام سيبويه على الألفاظ تقسيمه، إذ يقول : (إن من كلامهم اتفاق اللفظين والمعنى

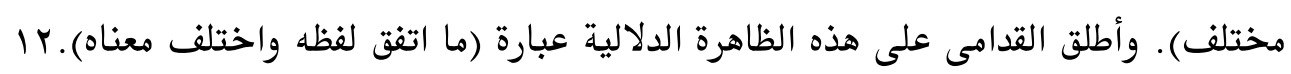
قد كان أول التعريف "وقعنا عليه" لمصطلح هذا العلم في كتاب ابن الجوزي (نزهة الأعين النواظر في علم الوجوه والنظائر)، ويرجع إلى القرن السادس، أي بعد أربع قرون من أول تأليف وصلنا في هذا الموضوع، وقوله كما يلي: أن تكون الكلمة الواحدة قد ذكرت في مواضع من القرآن الكريم على لفظ واحد، وحركة واحدة، وأريد بكل مكان معنى غير الآخر. فلفظ كل كلمة ذكرت في مواضع النظير للفظ الكلمة

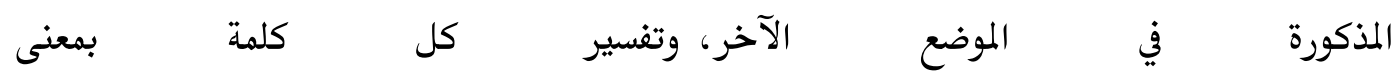
غير معنى الآخر فهو الوجوه، فإذن النظائر: اسم للأفاظ، والوجوه: اسم للمعاني، فهذا الأصل في وضع كتب الوجوه والنظائر، والذي أراد العلماء بوضع كتب الوجوه والنظائر أن يعرفوا السامع لـ هذه النظائر أن معانيها تختلف، وأنه ليس المراد بهذه اللفظة ما أريد بالأخرى فالكلمة المختلفة، كبيت وفرس، ورجل، وما ذكر في موضوع واحد من القرآن كسجيل، وما ذكر في عدة مواضع بمعنى واحد، كل هذا لا يعد من ألفاظ الوجوه. وكذلك الصورة المختلفة للمادة الواحدة

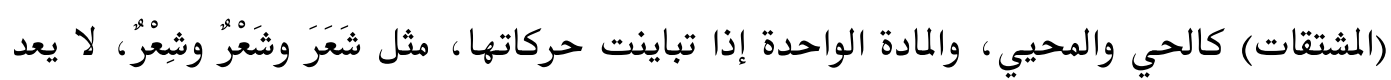
أيٌٌ منها لفظا واحدا، لذلك لا ينبغي أن يدخل بين ألفاظ الوجوهبا وبحسب تعريف ابن الجزي أيضا، تكون الوجوه هي المعاني المختلفة، المقصود كل منها في موضع غير الآخر، حيث ذكر اللفظ في مواضع عدة وقصد به في كل معنى غير الذي قصد به في الموضع الآخر.

أما النظائر فهي بحسب تحديد ابن الجوزي لها "اسم للألفاظ"، فلفظ كل كلمة ذكرت في

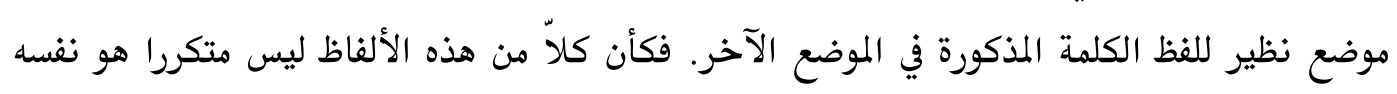
في كل من المواضع ، بل هو "نظير" لآخر يشبهه في الشكل، ويخالفه في المعنى، لذا لم يكن نفسه

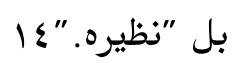

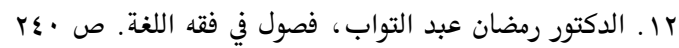

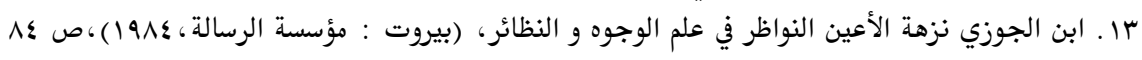

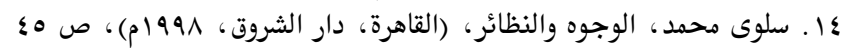

'A Jamiy, Jurnal Bahasa dan Sastra Arab Volume 07, No. 1,Juni 2018 
فيفهم من هذا التعريف أن المراد بالنظائر اتحاد الكلمة الواحدة في اللفظ، والمرادبالوجوه ا ختلافها في المعنى، فالنظائر اسم للألفاظ، والوجوه اسم للمعاني، وقد ذهب إلى هذا التعريف حاج ي خليفة أيضا. 10 ب.) أنواع الوجوه والنظائر يقول ابن الجوزي في كتابه " نزهة الأعين النواظر في علم الوجوه والنظائر : "وأعلم أن معنى الوجوه والنظائر أن تكون الكلمة واحدة، ذكرت في مواضع من القرآن على لفظ واحد، وح

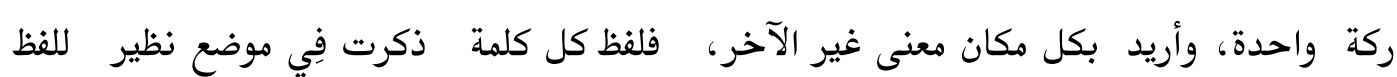

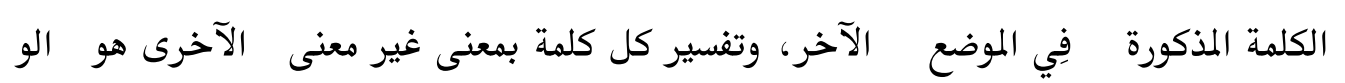

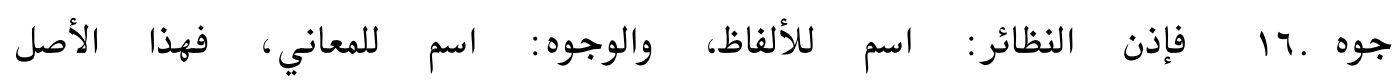

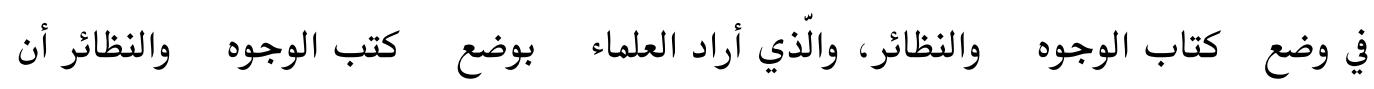

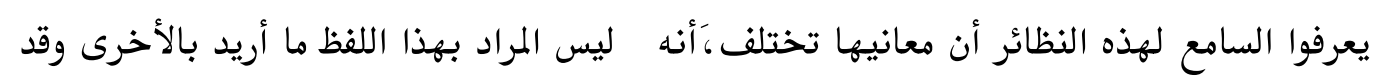

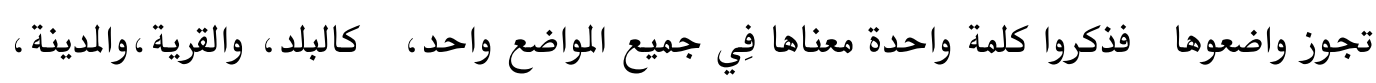

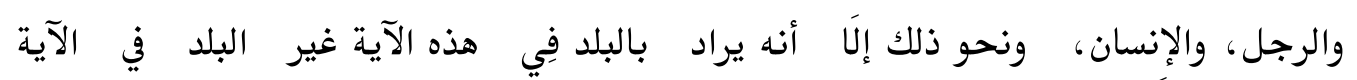
الأخرى وبهذه القرية غير القرية في الأخرى فحذوا بذلك حذو الوجوه والنظائر الحقيقيّة فعرف الباحث أن هذه الأسماء كما ذَكروها.ويستنتج من هذا النص، أن الوجوه والنظائر تنقسم إلى : (1)

( ) الوجوه والنظائر الحقيقية

الوجوه والنظائر الحقيقية هي: أن تكون للمفردة القرآنية نظائر بوجوه مختلفة

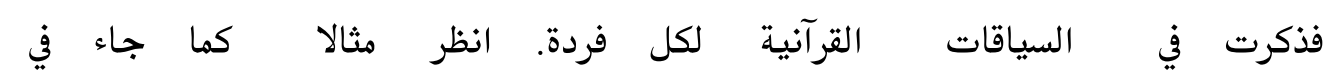

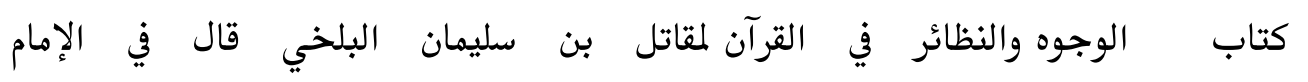

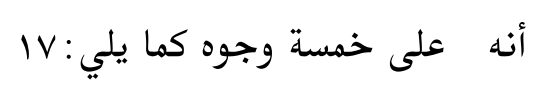

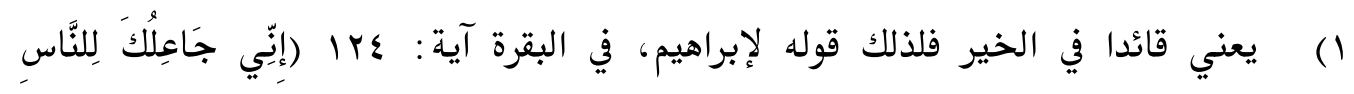
إِمَامًا ) يعني قائدا في الخير مقتدي بسنتك وهديك. 
r الإمام بمعنى: كتاب أعمال بني آدم فلذا قول سبحانه في بني إسرائل في سورة

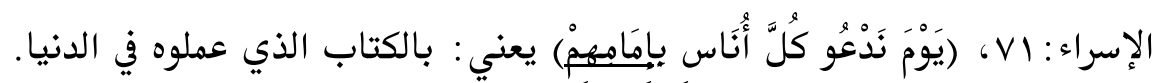

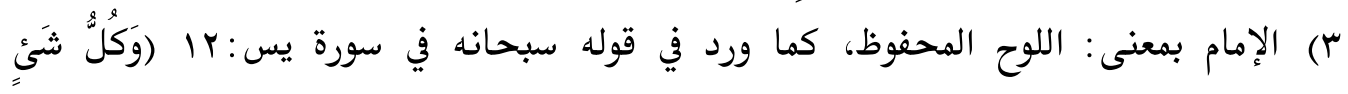

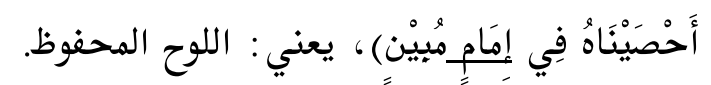

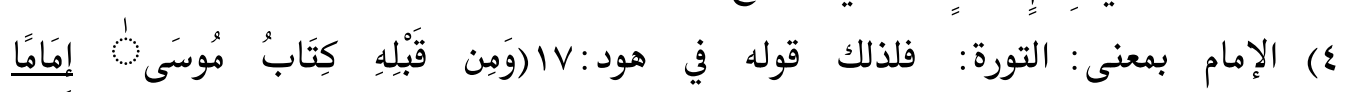

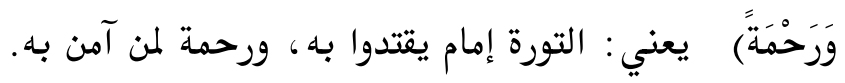

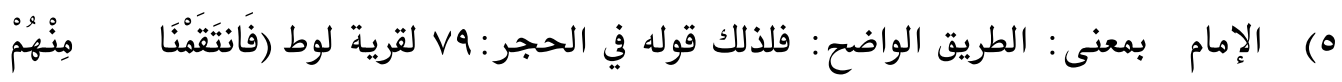

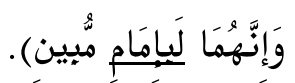

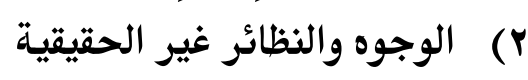

الوجوه والنظائر غير الحقيقية هي: وقال عنها ابن الجوزي : وقود تجوز واضعوهافذك

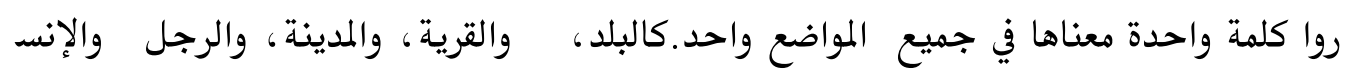

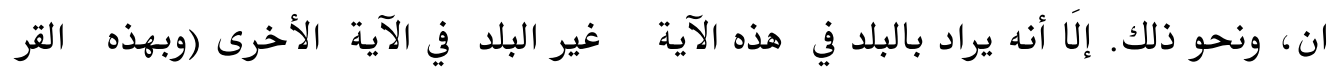

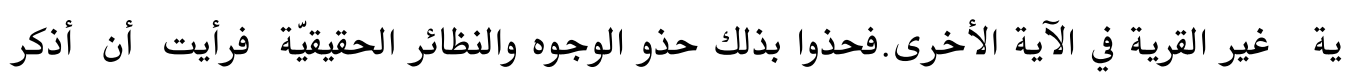

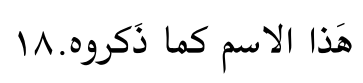

1) الأسماء المتكافئة : يقول ابن تيمية في مقدمة أصول التفسير: الأسماء المتكافئة التيبين

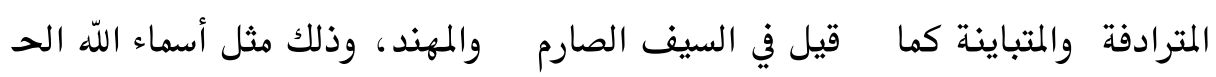

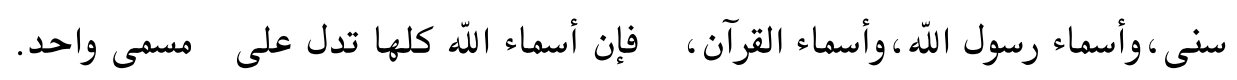

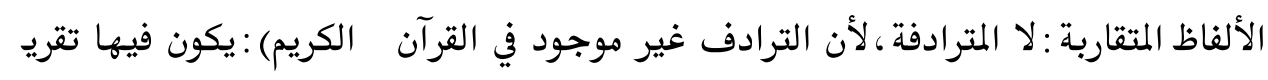

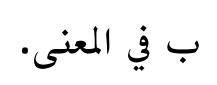

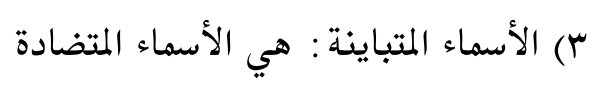
§) اللفظ المشترك: ما اتحد لفظه واختلف معناه

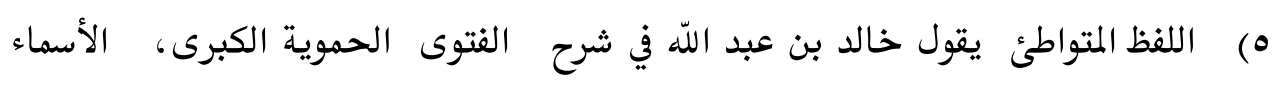

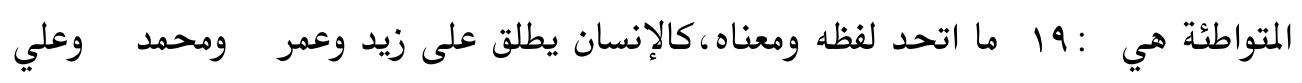

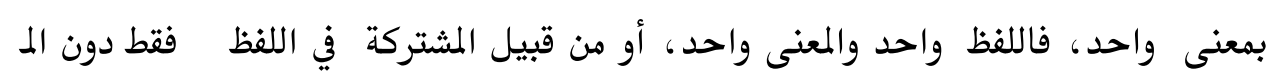

\section{'A Jamiy, Jurnal Bahasa dan Sastra Arab}

Volume 07, No. 1,Juni 2018 
عنى، فهي مشتركة في اللفظ لكن معناها يختلف باختلاف الأفراد، فتقول مثلاً: نور

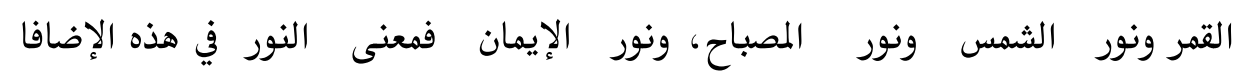
ت مختلف، وذلك من جهة القوة والشدة والضعف، وما إلى ذلك.

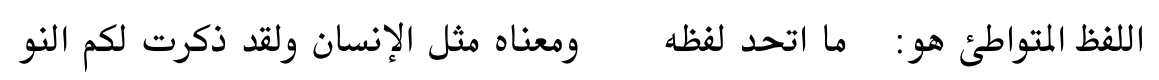

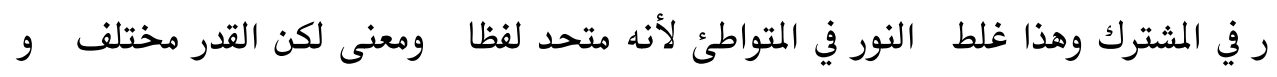

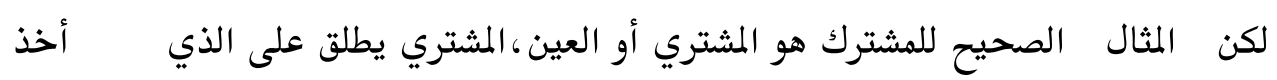
الشيء بثمن.

بعد أن يعرف الباحث أصناف المفردات تقال الوجوه والنظائر على الحقيقية وغير الحقيقية بمعنى

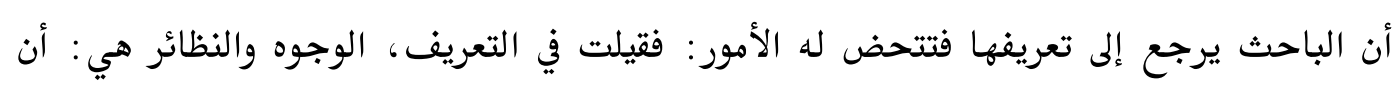

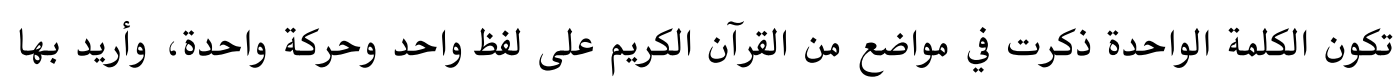

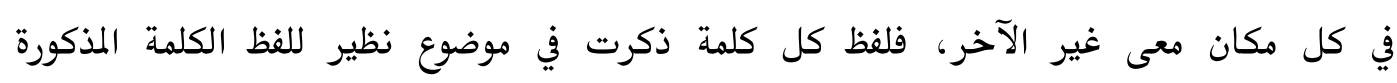

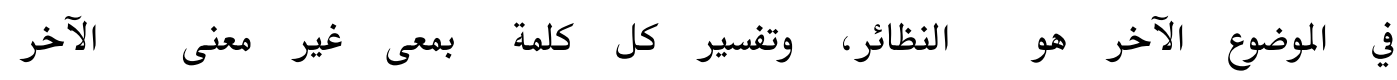

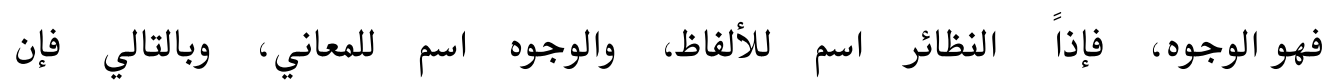

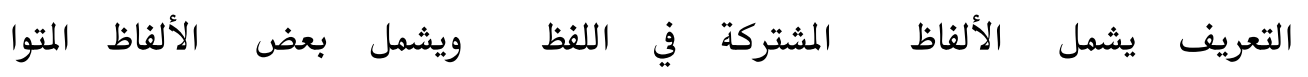

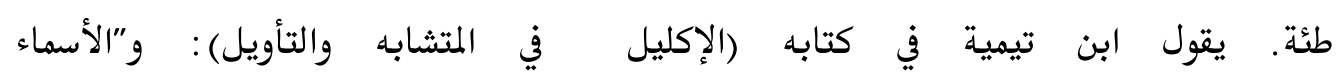

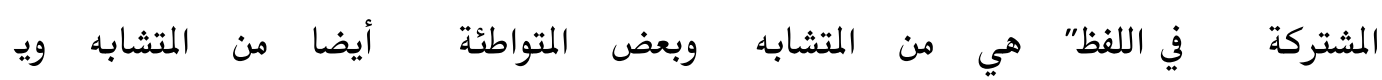

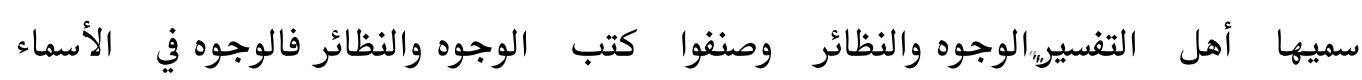

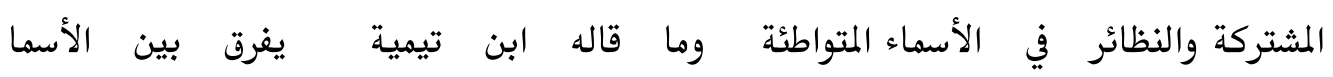

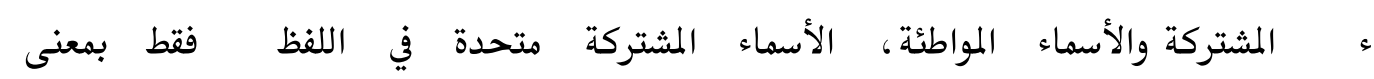

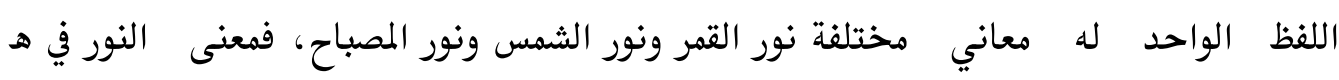

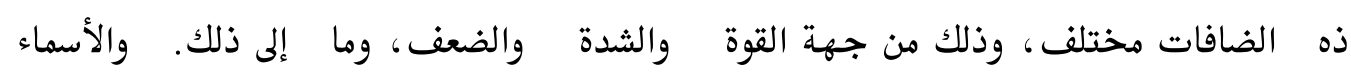
المتواطئة متحدة في اللفط والمعنى أي اتحد لفطه ومعناه.

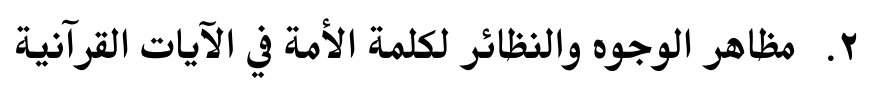
أ) الوجوه والنظائر لكلمة الأمة في الآيات القرآنية

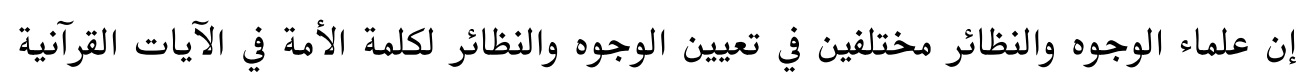

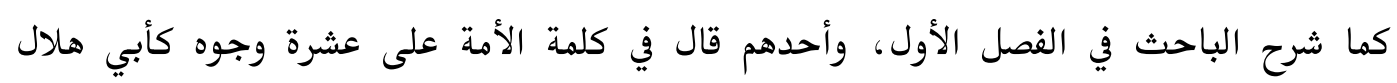

\section{'A Jamiy, Jurnal Bahasa dan Sastra Arab Volume 07, No. 1,Juni 2018}


العسكري،وثانيهم قال في كلمة الأمة على تسعة وجوه كمقاتل بن سليمان ، وثالثهم قال في كلمة الأمة على ثمانية وجوه كهارون بن موسى، ورابعهم قال في كلمة الأمة على خمسة وجوه كابن

الجوزي.

وبخلاف على هذا البحث يعني بعد تحليل الباحث القرآن الكريم بطريقة تلاوته من أوله

إلى أخره، وبعون آراءهم وجد الباحث ثلاثة عشر وجها لكلمة الأمة كما يلي:

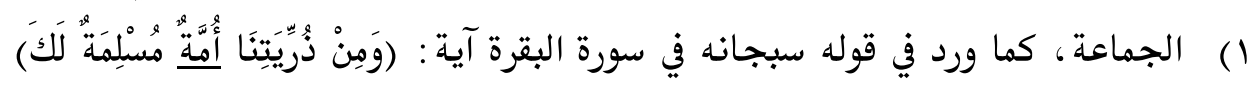

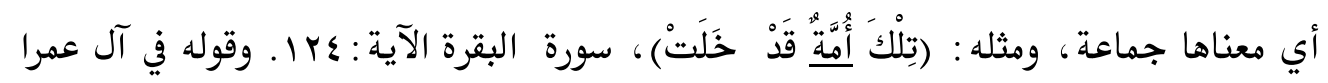

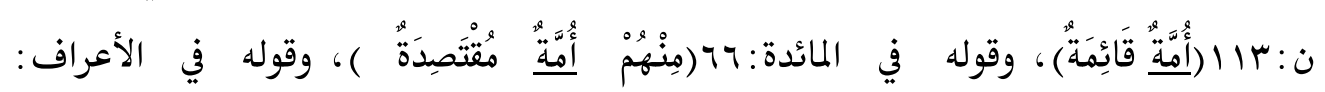

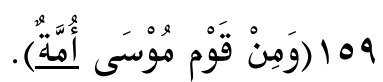

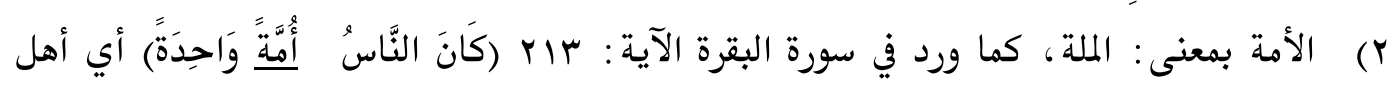

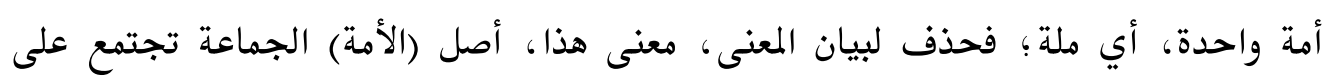
دين واحد، ثم يكتفي بالخير عن "الأمة" من الخير عن "الدين" لدلالتها عليه كما قال جل

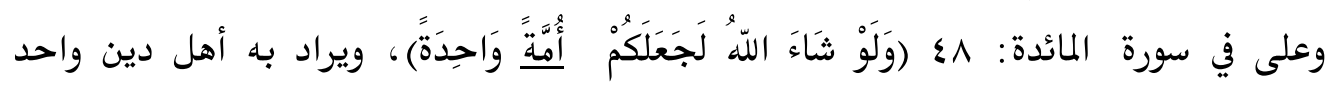
وملة واحدة فوجه ابن عباس في تأويله قوله : "كان الناس أمة واحدة" إلى أن الناس كانوا أهل دين واحد حتى اختلفوا. وكما قال اللّه تعالى في سورة يوسف الآيةة: بروَاسْأَل القَرْيَةَ)، وسميت الملة أمة؛ لاجتماع أهلها عليها، ويجوز أن يقال: أنها سميت أمة لأنها تقصد وتتبع ، والمراد هنا أن الناس.

r) الأمة بمعنى: أهل الإسلام بعينه، ‘ُ وقال اللّ تعالى في سورة يونس الآية 19 (مَا كَانَ

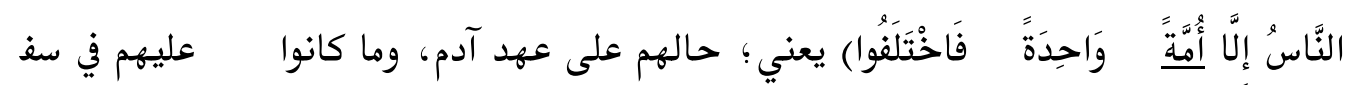

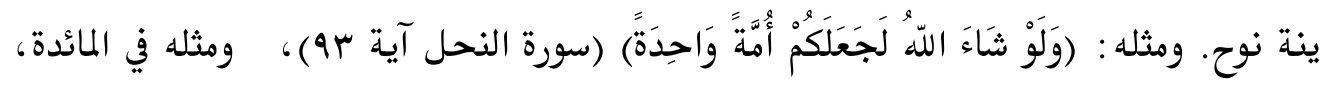
أي: لو شاء اللّه لجعلكم متفقين على الإسلام قهرا.كما قال الله تعالى في الشعراء: ؟(فَظَلَتْ أَعْنَافُهُمْ لَهَا خَاضِعِيْنَ)

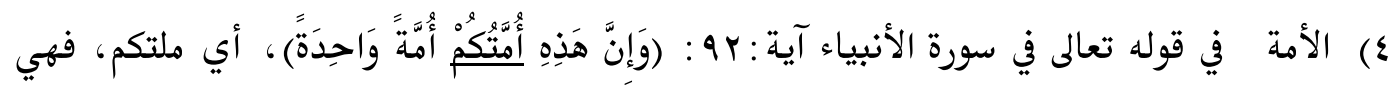

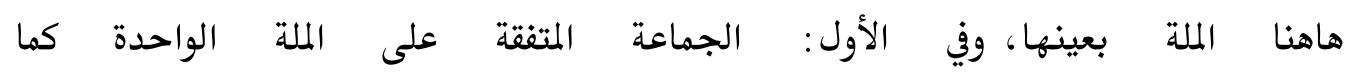

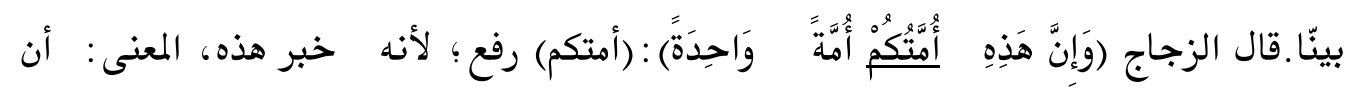

\section{'A Jamiy, Jurnal Bahasa dan Sastra Arab \\ Volume 07, No. 1,Juni 2018}


هذه أمتكم في حال اجتماعها على الحق، فإذا افترقت فليس من خالف الحقد خلا فيه 1، فنصب: (أمة واحدة) على الحال. وقرئ: (أمة واحدة) على أنها ربر بعد خبر، ومعناه: إن هذه أمة واحدة سورة ليست آية أمما، ويجوز أن يكون نصب : (أمتكم) على التوكيد كأنه قاله : إن أمتكم طلها أمة واحدة.

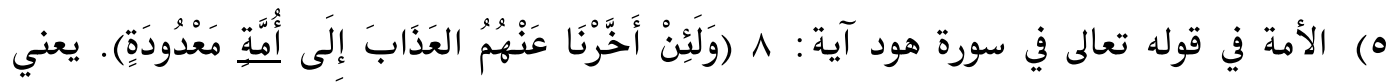

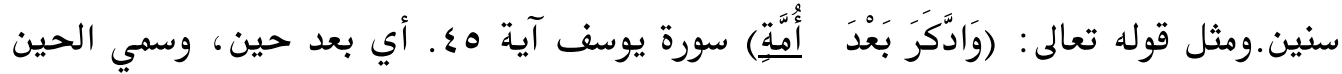
أمة ؛ لأنه جماعة أوقات و شهور. هو على حذف: أي بعد حين أمة ، أي : جماعة.

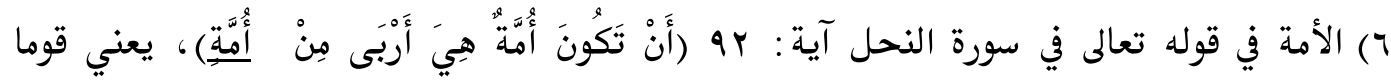
يكونون أربى من قوم؛ أي: أكثر عددا، ومنه الربا؛ لأنه زيادة في أصل المال، ومثله ، قول

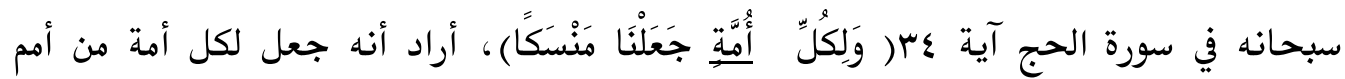
التي خلت فيها الرسل منسكا؛ وهو الذبائح التي كان أمرهم أن يتقربوا بها إلى اللّ ولم يرد جميع الأمم؛ لأنه يجعل للمجوس وعباد الأصنام مناسك.

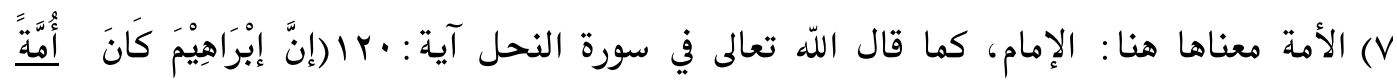
قَانِتًا)، أي إماما يقتدي بـه في الخير. ^) الأمة بمعنى: أمة كل رسول؛ يعني: من بعث إليه الرسل من أمثال عاد، وثمود، ولوط؛ وهو

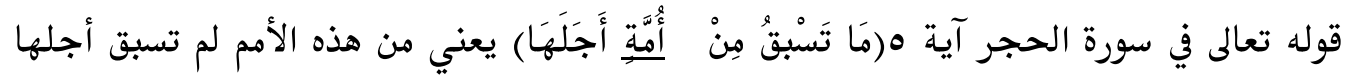

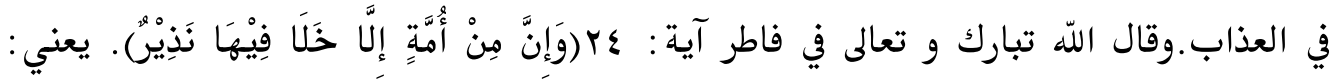
الأمة من هذه الأمم؛ لأن الفرس والهند والزنج أمم لم يبعث فيها نذير، إنما كانوا متعبدين بتصديق من بعث في غيرهم من الأنبياء، على حسب ما يعبدوا بتصديق محمد صلى الله عليه وآله، ولم يبعث فيهم.

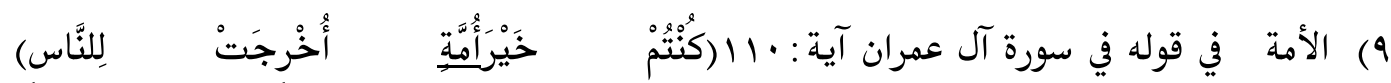

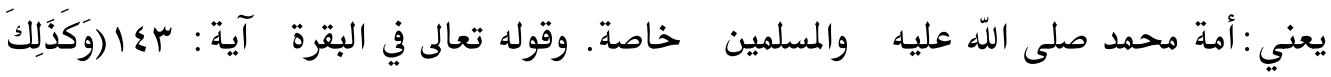

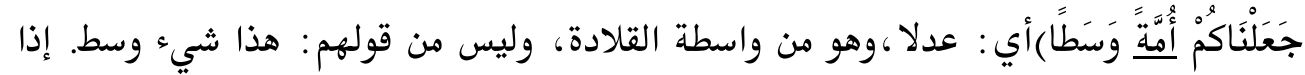
كان بين العالي والمنحة، ومنه قول النبي صلى الله عليه وسلم (أنا أوسط قريش نسبا).

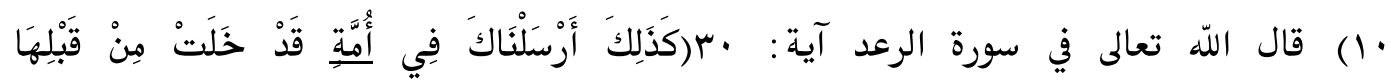

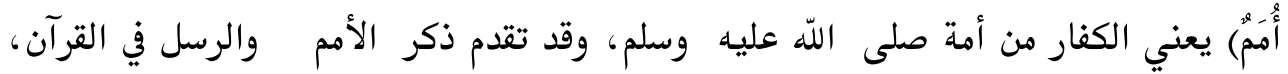

\section{A Jamiy, Jurnal Bahasa dan Sastra Arab Volume 07, No. 1,Juni 2018}


فعطف قوله (وَكَذَلكِكَ أََْهَلْنَاكَ) على أولئك الرسل فكأنه قال :كما أرسلنا إلى أمم رسلا من قبل أرسلناك إلى أمة، يعني هذه الأمة،و، (خَلَتْ) أي هضت ولم تبق منهم باقية. وفي هذا

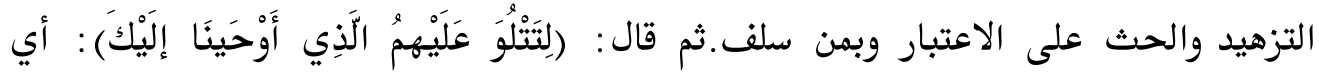
لتتلوه عليهم وتدعوهم إلي العمل به. فحذف ذلك.

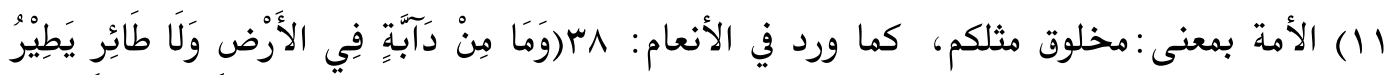

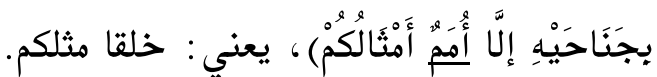

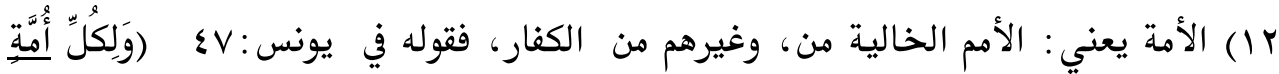

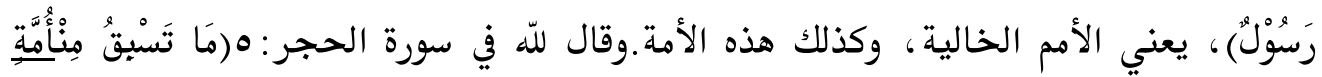

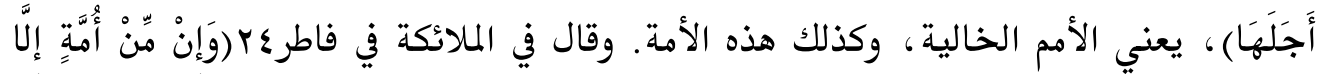
خَلَا فِيْهَا نَذِيْرِ)، يعني : الأمم الخالية.

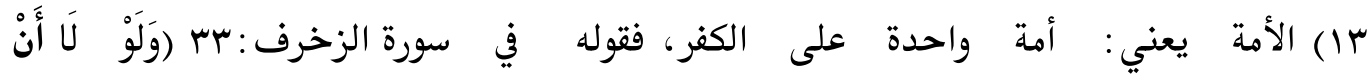

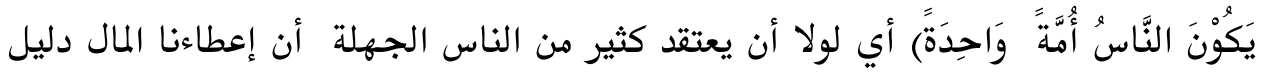
على محبتنا لمن أعطيناه، فيجتمعون على الكفر لأجل المال. ب. تحليل مظاهر الوجوه والنظائر لكلمة الأمة في الآيات القرآنية كما ذكر الباحث في معالم الموضوع عن تعريف الوجوه والنظائر مسبقا، فتبين عند الباحث أن الوجوه تذكر في كلمة واحدة لها معاني متعددة، والنظائر في مشابهة المعنى لكلمة واحدة مع اختلاف الجملة. والآن سيحاول الباحث أن يحلل عن الوجوه والذظائر من كلمة الأمة في الآيات القرآنية وجها بوجه ، فلذا سيحللها الباحث مستعينا بالجداول التالية:

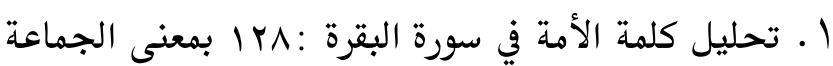

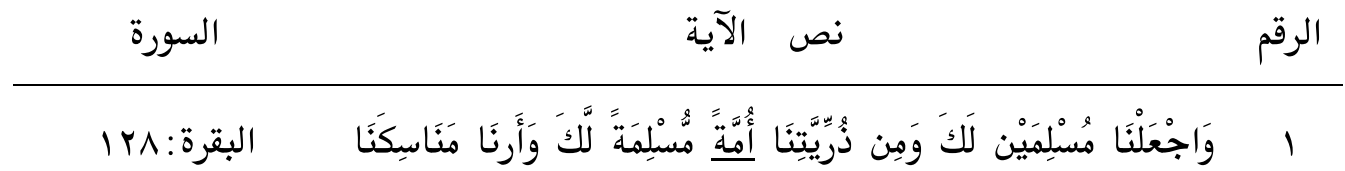

وَتُبْ عَلَيْنَا

\section{'A Jamiy, Jurnal Bahasa dan Sastra Arab} Volume 07, No. 1,Juni 2018 
والمقصود من هذه الآية: أي و واجعل من ـريتا جماعة

مخلصة لك، ليستمر الإسلام لك بقوة الأمة وتعاون

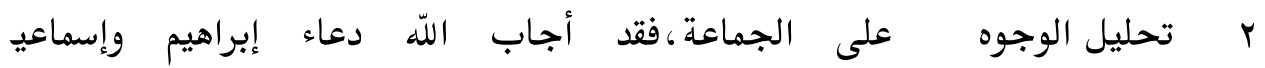

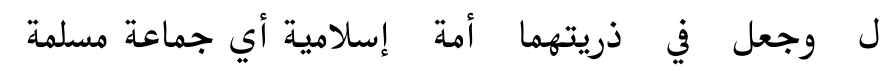

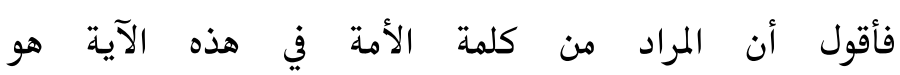

الجماعة من الأمة الإسلامية.

r م أما النظائر لكلمة الأمة في سورة البقرة: البمعنى الجماعة هي على سبعة نظائر كما يلي:

\begin{tabular}{|c|c|}
\hline 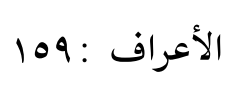 & وَمِنْ قَوْم مُوسَى أُمَّةَّة يَهْدُونَ بالْحَقِِّ وبه يعدلون \\
\hline المائدة : ج7 & 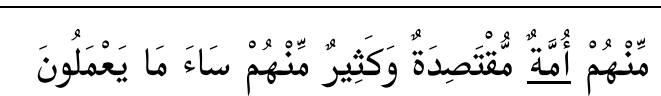 \\
\hline
\end{tabular}

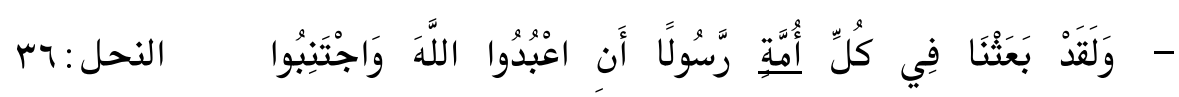
الطَّاَْوتَتْ

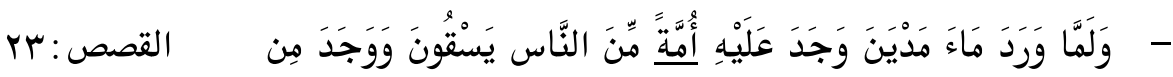

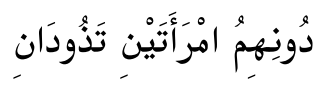

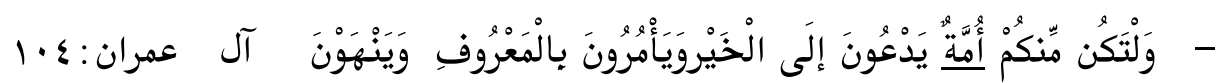
عَن الْنْكَرَ

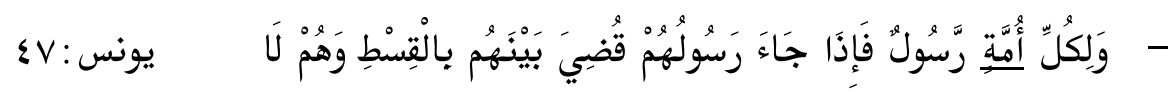

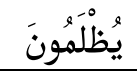

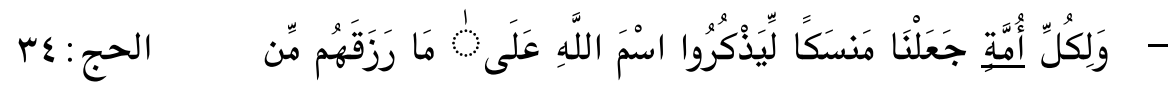
بَهِيمَتِة الْنَنْعَامِ

\section{'A Jamiy, Jurnal Bahasa dan Sastra Arab}


Y r تحليل كلمة الأمة في سورة الزخرف :r ب بمعنى الدين

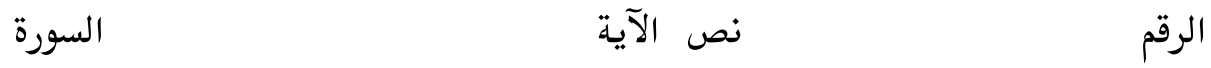

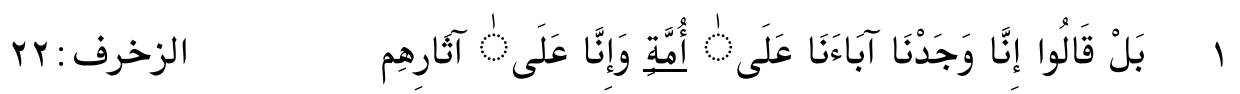

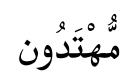

أي كان الناس على الإيمان والفطرة المستقيمة أي على دين واحد،

فاختلفوا وتنازعوا فبعث الله النبيين مبشرين ومنذرين ليحكم بينهم

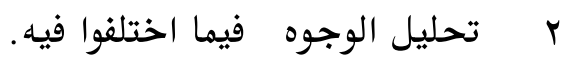

فأقول أن هذه الآية تدل على أن آدم وذريته كانوا مسلمين وهم

على دين واحد وهو الإسلام. فأقول أن المراد من كلمة الأمة في هذه

الآية : الملة الواحدة.

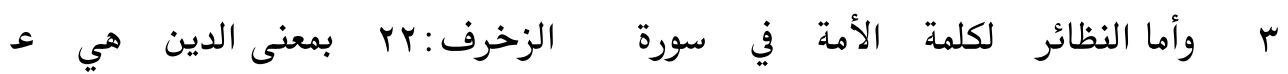
لى خمسة نظائر هي كما يلي:

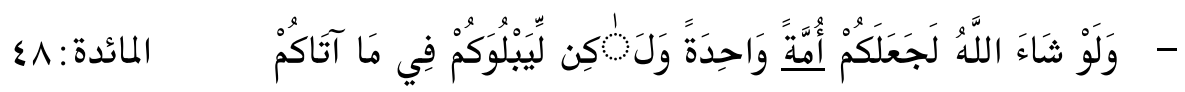

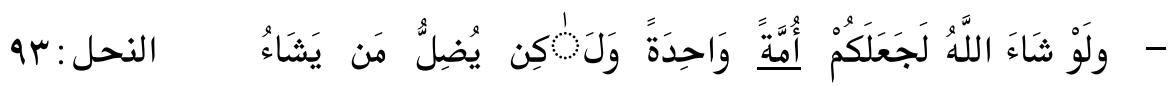
وَيَهْدِيْ مَنْ يَشَاءُ

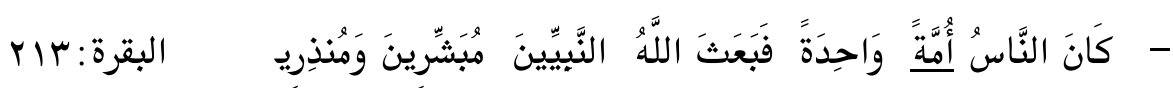

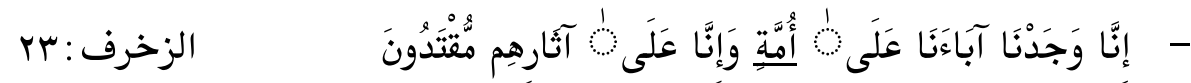

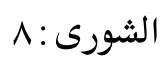

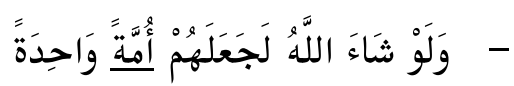

\section{'A Jamiy, Jurnal Bahasa dan Sastra Arab}




$$
\text { r.تحليل كلمة الأمة في سورة يونس : } 19 \text { بمعنى أهل الإسلام بعينه }
$$

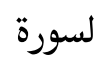
نص الآية

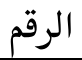

ا 19 : 19

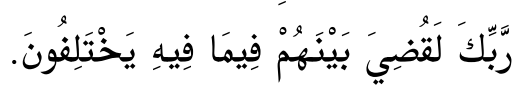

أي كان الناس من لدن آدم عليه السلام أهل الإسلام

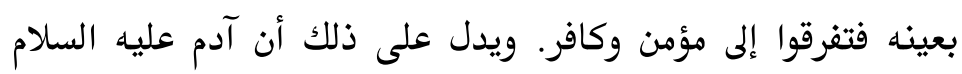

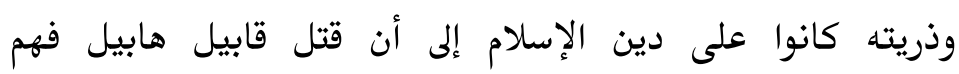

r ب ت تحليل الوجوه اختلفوا.

فأقول أن هذه الآية تدل على أن الناس كانوا جم

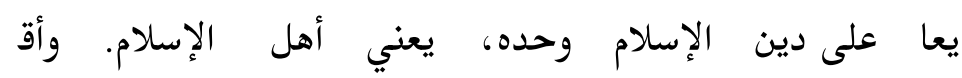

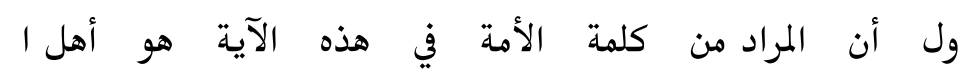

لإسلام بعينه

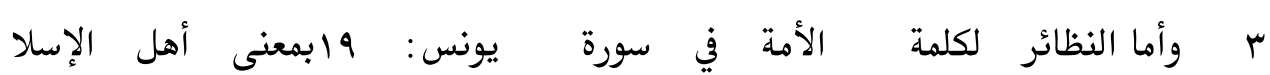

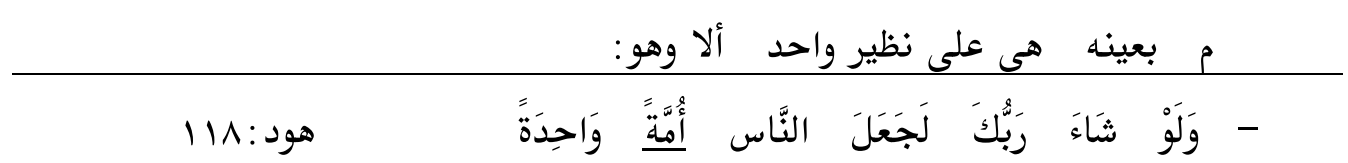

$$
\text { ع .تحليل كلمة الأمة في سورة هود: } 1 \text { بمعنى الحين }
$$

الرقم

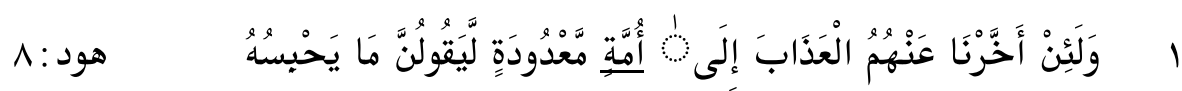




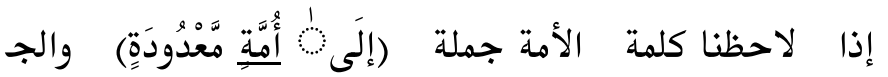

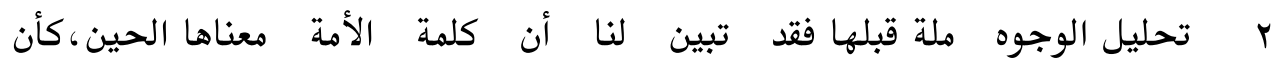
اللّه

يقول:ولئن أخرنا عنهم العذاب إلى مدة من الزمان قل

$$
\text { يلة يعني إلى أجل محدود }
$$

فأقول أن الوجه من كلمة الأمة في هذه الآية هو الحين.

ب م موأما النظائر لكلمة الأمة في في سورة هود : 1 : بمعنى الحين هي على نظير واحد هو كما يلي :

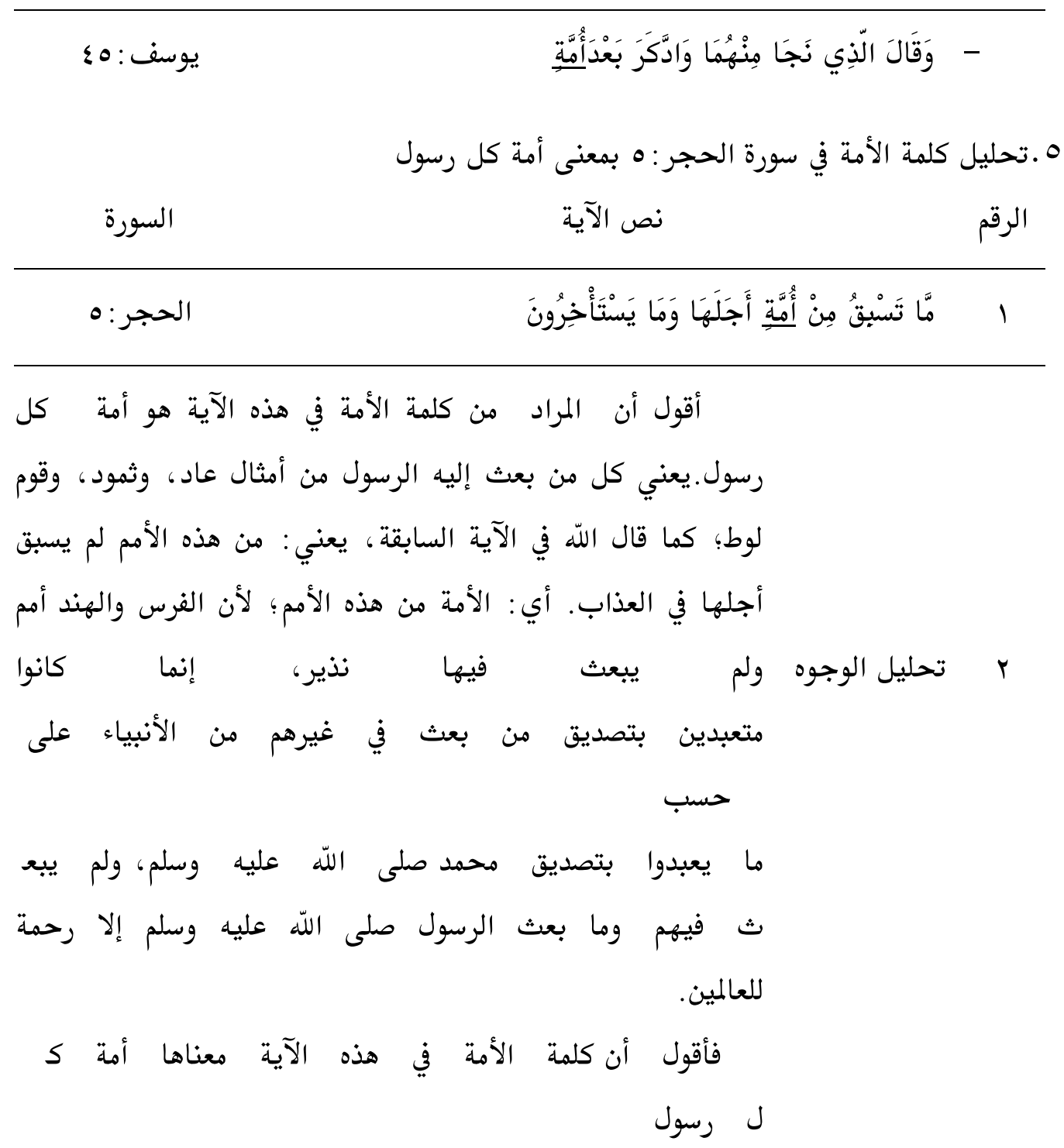

'A Jamiy, Jurnal Bahasa dan Sastra Arab Volume 07, No. 1,Juni 2018 
mi

ب وأما النظائر لكلمة الأمة في هذه الآية : هي على نظير واحيد وهو كما يلي:

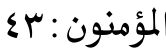

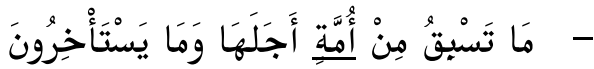

7 . تحليل كلمة الأمة في سورة ل عمران: •11 بمعنى أمة محمد والمسلمين خاصة نص الآية

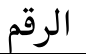

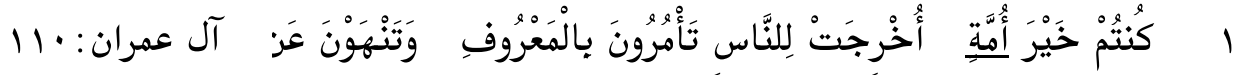

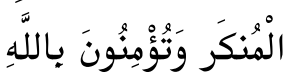

إذا لاحظنا هذه الآية الكريمة أن للّ لن يبعث دعاة من

غير المسلمين ليأمرو بالمعروف وينهو عن المنكر إلا مسلمين خاصة

r ت تحليل الوج بل إنهم أهل النصارى وأهل اليهود وسواهما يكونون مدعوين إلى

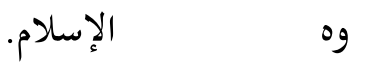

فأقول أن المراد من كلمة الأمة في هذه الآية هو أمة محمد

والمسلمين خاصة.

r م أما النظائر لكلمة الأمة في سورة آل عمران : • 11 بمعنى أمة محمد والمسلمين خاصة هي على نظيرين ألا وهما :

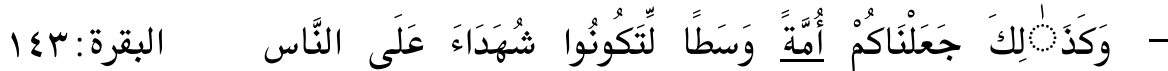
وَيَكُونَ الرَّسونُ عَلَيْكْمْ شَهَيدًا

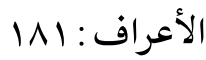

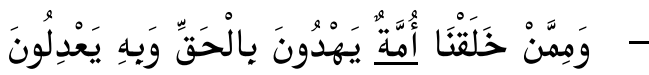
V . تحليل كلمة الأمة في سورة الرعد : · ب بمعنى الكفار من أمة محمد

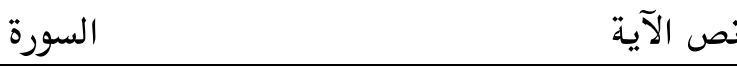
الرقم

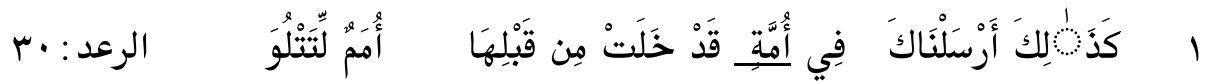

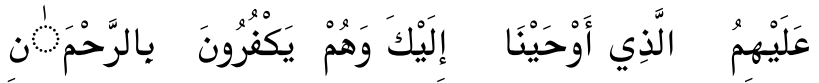




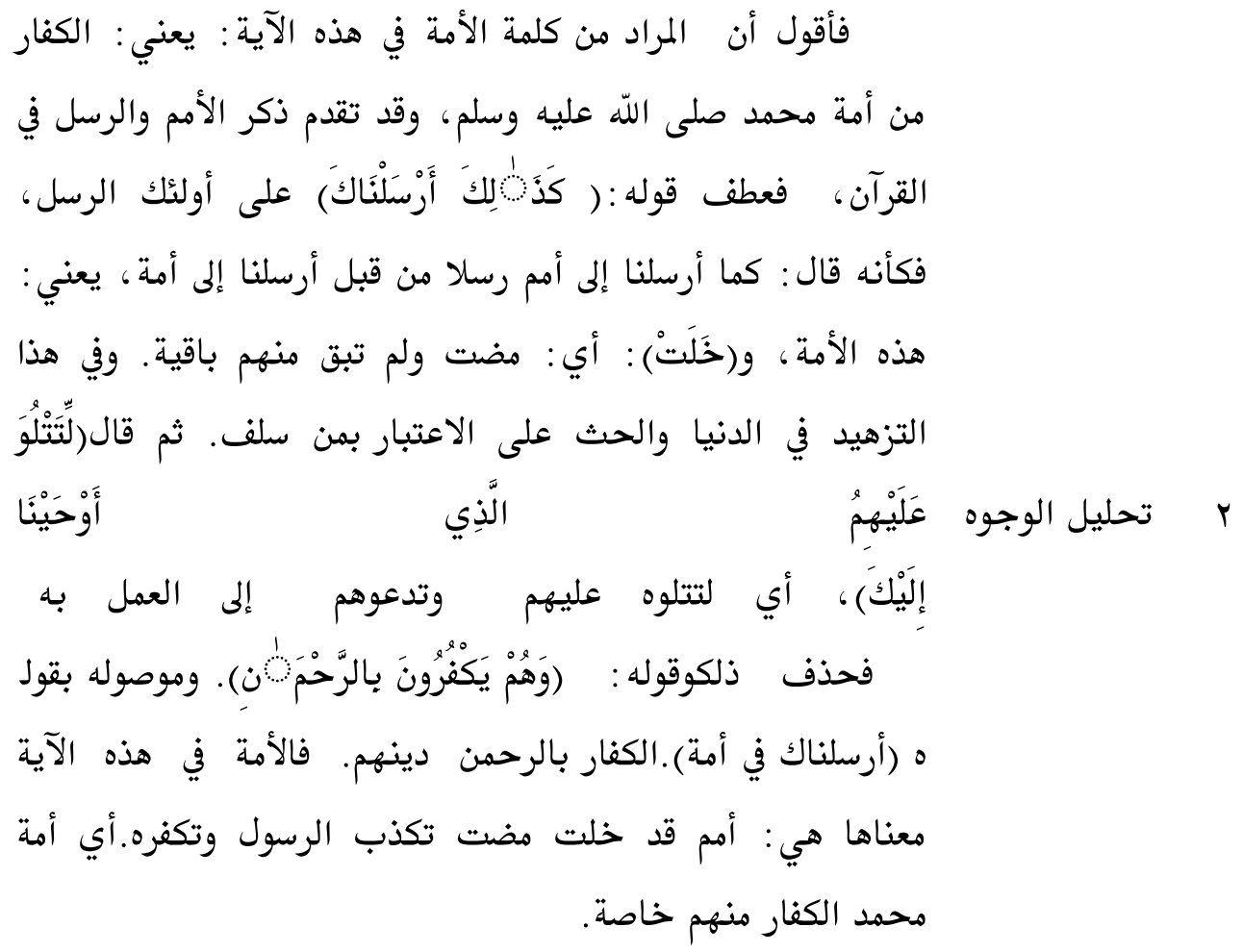

r م أما النظائر لكلمة الأمة في سورة الرعد : • بمعنى أمة محمد الكفار منهم خاصة. هي على نظير واحد هو كما يلي :

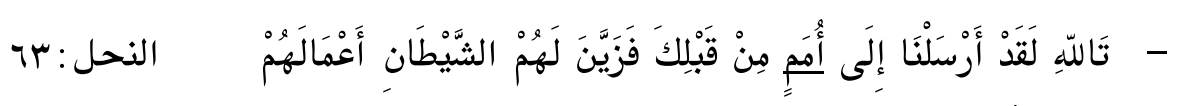

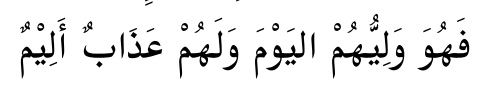

^.تحليل كلمة الأمة في سورة الأنعام: ب ب بمعنى خلق أمثالكم

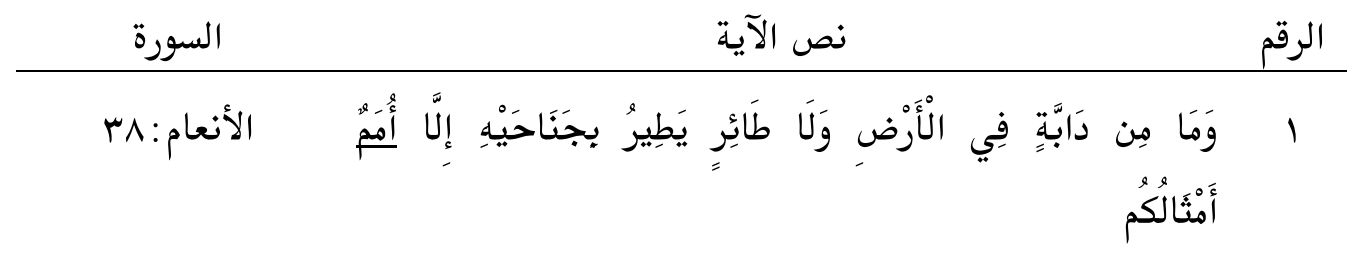

\section{A Jamiy, Jurnal Bahasa dan Sastra Arab


أي إلا طوائف مخلوقة مثلكم خلقها الله وقدر أحوالها وأرزاقها

$$
\text { وآجالها. }
$$

إذا لاحظنا كلمة الأمة في هذه الآية الكريمة فهي توضح

r ت تحليل الوجوه هيئة كلمتين قبلها وهما (دَابَّةٍ وطائر) على أنهما

خلق مثلنا ومخلوقة خلقها الله في الدنيا كما خلقنا

$$
\text { اللّه فيها }
$$

فأقول أن المراد من كلمة الأمة في هذه الآية هـ

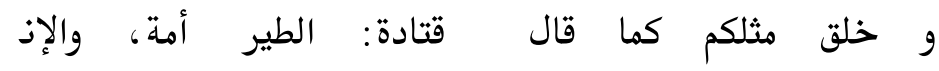

سان أمة، والجن أمة

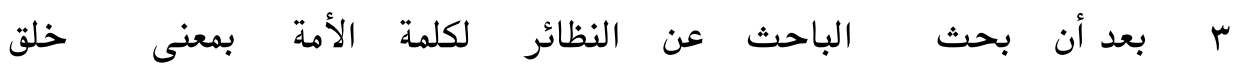

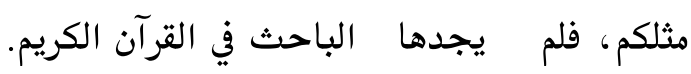

\begin{tabular}{|c|c|c|}
\hline السورة & نص الآية & الرقم \\
\hline الزخرف :سب & وَلَوَنَا أَنَ يَكَونَ النَّاسُ أُمَّةَة وَاحِدَةً & 1 \\
\hline
\end{tabular}
9 9 تحليل كلمة الأمة في سورة الزخرف: بr بمعنى أمة واحدة على الكفر

انظر إلى قوله سبحانه :(ولولا أن يكون الناس أمة واحدة)

أي لولا أن يعتقد كثير من الناس الجهلة أن إعطاءنا المال دليل

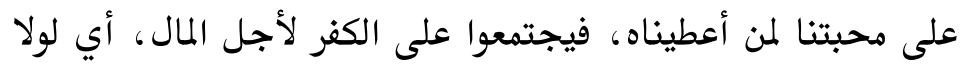

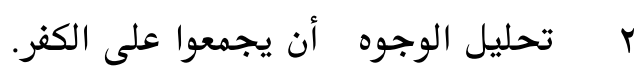

فأقول أن المراد من كلمة الأمة في هذه الآية هو أمة واحدة على لئل

الكفر.

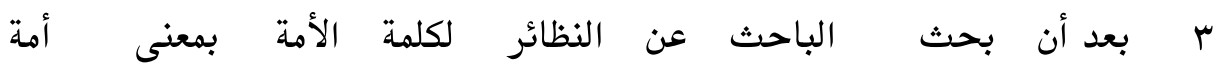

$$
\text { واحدة على الكفر، لم يجدها الباحث في القرآن الكريم }
$$

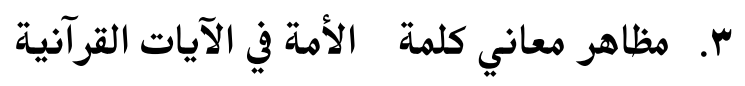

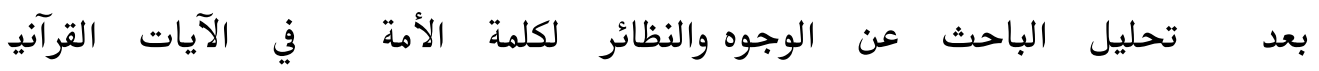

ة كما ذكرها الباحث في الفصل الثاني، فكتب الباحث هنا فكرة البح

\section{'A Jamiy, Jurnal Bahasa dan Sastra Arab}


ث الثانية حيث أن الباحث سيحلل كل كلمة الأمة التي تتضمن على الوجو م والنظائر في الآيات القرآنية آية فآية، فيكون تحليلها من حيث معانيها فيما يلي: أ. أ. معني الأمة المعجمي

الأمة ج أمم: الجنس، والأمة، والدين، وفرقة الدين، والوقت، والإمام الأمة :

rI.

الوالدة. وجماعة من الناس أكثرهم من أصل واحد، وتجمعهم موروثة، ومصلح، وأماني واحدة، أو يجمعهم أمر واحد من دين أو مكان أو ز ز

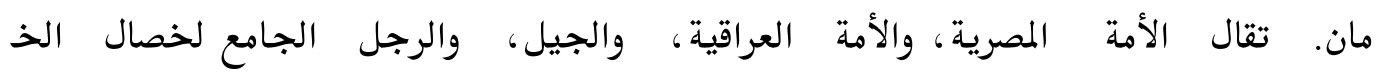

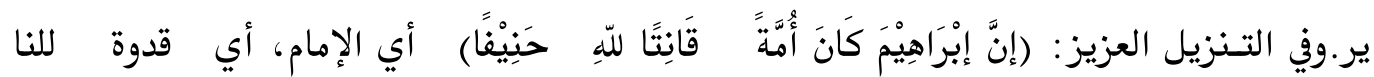

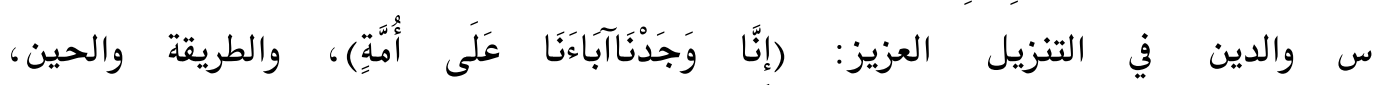

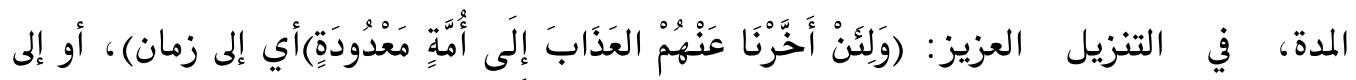

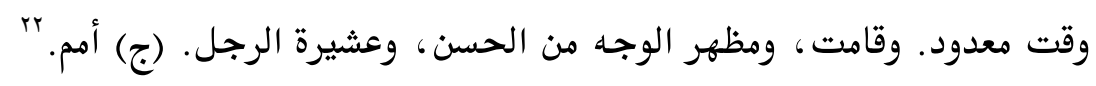
ب. تحليل مظاهر معاني كلمة الأمة في الآيات القرآنية

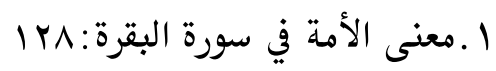

لفظ الأمة الرقم

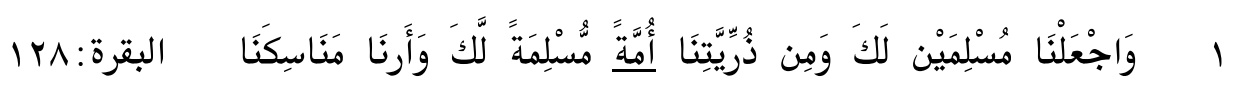
وَتَتُبْ عَلَيْنَا

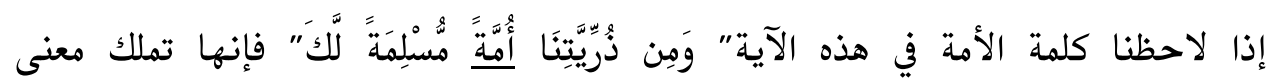
أساسيا:وهو جماعة، لأن الأمة أصلها جماعة من الناس، إذاً يكون معنى الآية هو ومن ذريتنا جماعة مسلمة لك. فأقول أن المعنى الأساسي من كلمة الأمة في هذه الآية : جماعة من ذريات إبراهم. Y ب المعنى الأمة في سورة الأعراف : 109

\begin{tabular}{|c|c|c|}
\hline السورة & لفظ الأمة & الرقم \\
\hline الأعراف : & 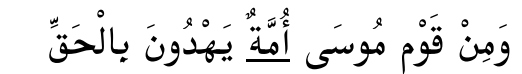 & $r$ \\
\hline
\end{tabular}

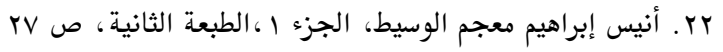

'A Jamiy, Jurnal Bahasa dan Sastra Arab Volume 07, No. 1,Juni 2018 


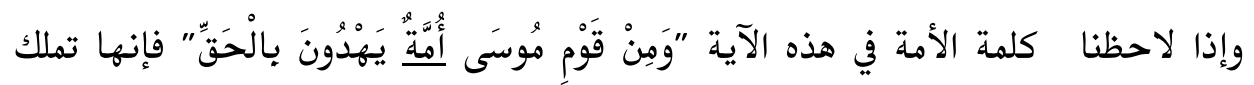

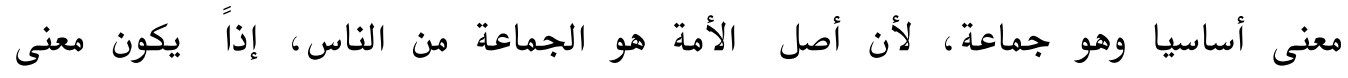

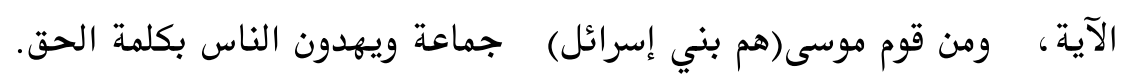

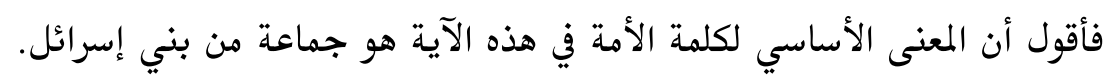

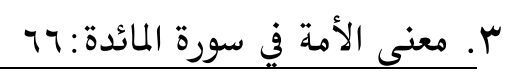

\begin{tabular}{|c|c|c|}
\hline السورة & لفظ الأمة & الرقم \\
\hline المائدة: 77 & 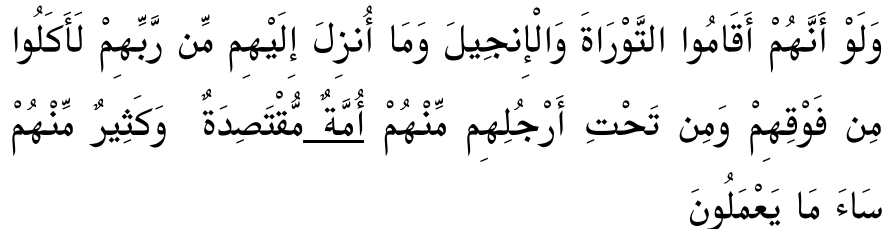 & $r$ \\
\hline
\end{tabular}

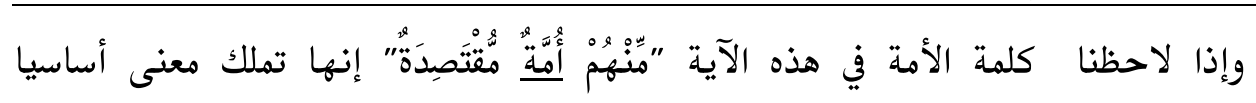

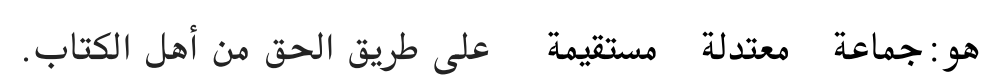

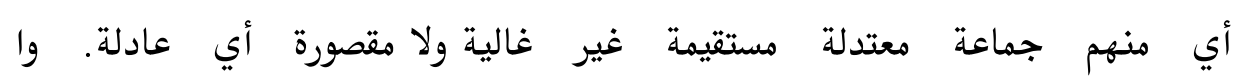

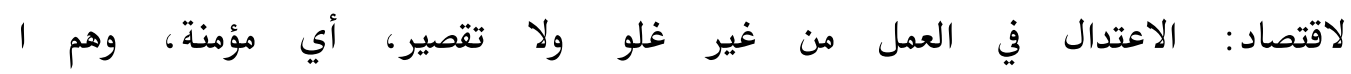

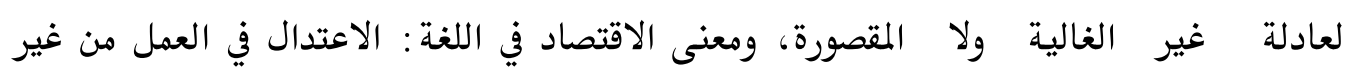

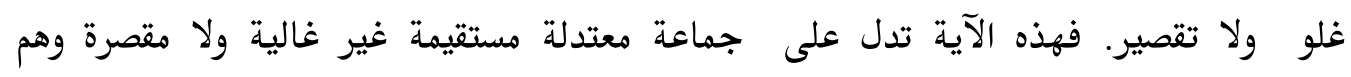
الذين آمنوا بمحمد صلى الله عليه وسلم كعبد اللّ سلام والنجاشي وسلمان.

فأقول أن المعنى الأساسي لكلمة الأمة في هذه الآية هو جماعة معتدلة مستقيمة من أهل التورة، والإنجيل، وأهل الفرقان.

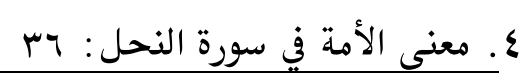

\begin{tabular}{|c|c|c|}
\hline السورة & لفظ الأمة & الرقم \\
\hline
\end{tabular}

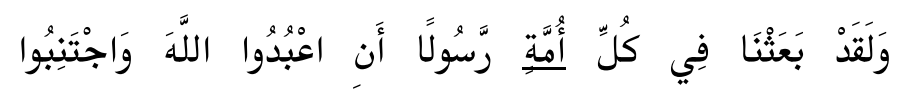

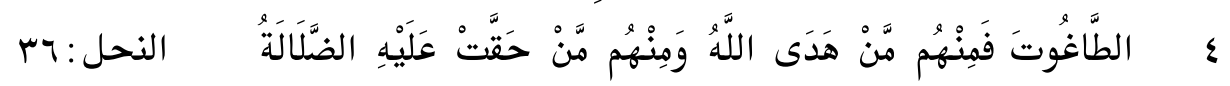

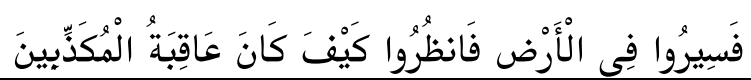

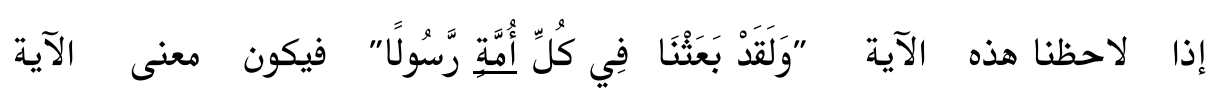

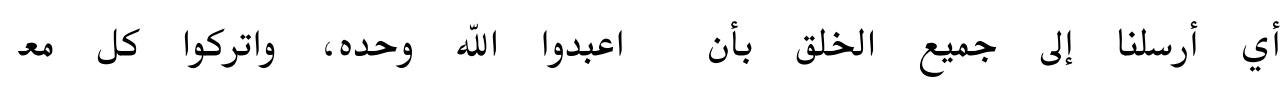

'A Jamiy, Jurnal Bahasa dan Sastra Arab Volume 07, No. 1,Juni 2018 
بود دون الله كالشيطان والكاهن والصنم، وكل من دعا إلى الضلال.يعني: كما بعثنا فيكم محمدا صلى الله عليه وسلم. يعني كما بعثناك في هؤلاء.

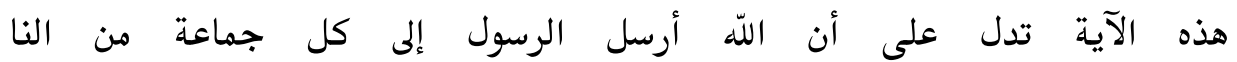
س ليعبدوا الله وحده، ويتركوا كل معبود دون الله كالشيطان والكاهن، والصنم.

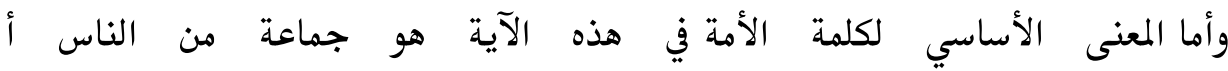
كان مؤمنا أو كافرا. ه. معنى الأمة في سورة القصص:س ب

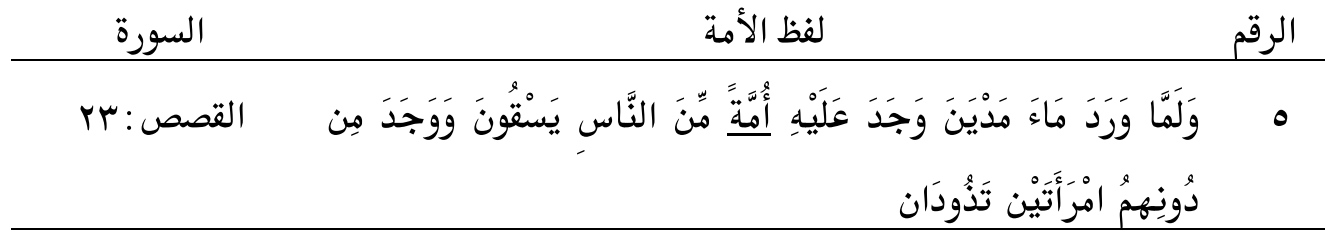

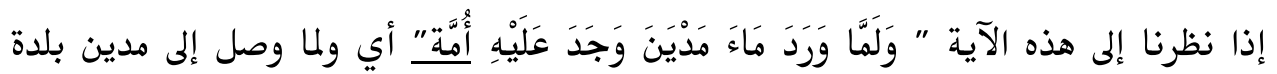
شعيب وجد على البئر الذي يسقي منه جماعة كثيرة من الناس يسقون مواشيهم. أي من إبلهم وغنمهم، ودوابهم المختلفة.

فأقول أن الأمة هنا معناها (جماعة كثيرة من الناس وهم الرعاة)،كما سار إليه علي شاهين في كتابه تفسير الخاون. بr فأقول أن المعنى الأساسي لكلمة الأمة في هذه الآية هو: جماعة كثيرة من الناس يعني: رعاة المواشي.

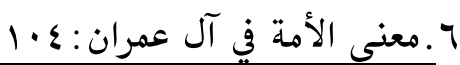

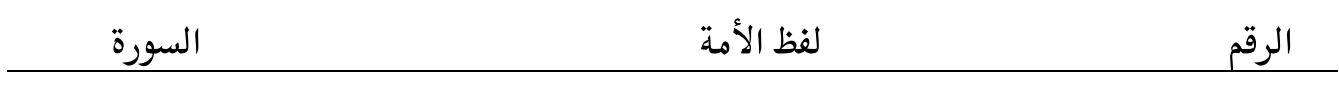

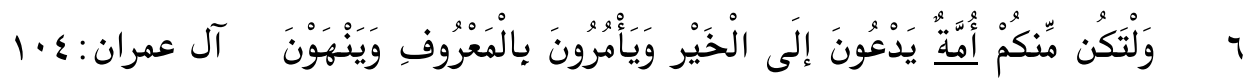
عَن الْنْكَر

إذا لاحظنا كلمة الأمة في هذه الآية إنها تملك معنى أساسيا هو: جماعة مؤمنة، وهم

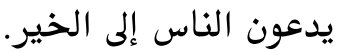
والمعنى الآية، ولتكن منكم أيها المؤمنون طائفة قوية الإيمان عظيمة الإخلاص، تبذل أقصى طاقتها وجهدها فى الدعوة إلى الخير الذي يصلح من شأن الناس، وفى أمرهم بالتمسك

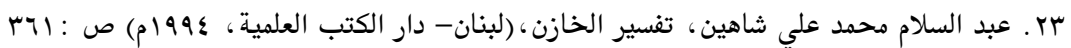


بالتعاليم وبالأخلاق التى توافق الكتاب والسنة والعقول السليمة، وفى نهيهم عن المنكر الذى يأباه شرع الله، وتنفر منه الطباع الحسنة. وكلمة الأمة في هذه الآية تدل على معنى جماعة أي جماعة مؤمنة يدعون الناس إلى الخير. فأقول أن المعنى الأساسي لكلمة الأمة هو جماعة قوية الإيمان عظيمة الإخلاص.

\begin{tabular}{|c|c|c|}
\hline السورة & لفظ الأمة & الرقم \\
\hline يونس : ع & 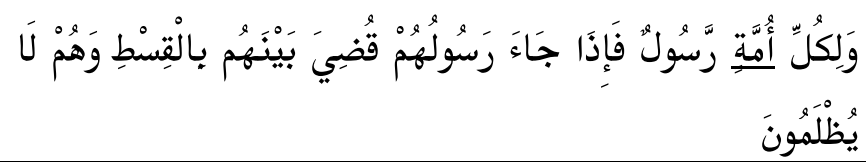 & V \\
\hline
\end{tabular}

أما كلمة "أمة" في هذه الآية لها معنى سياقي هو كما يلي:

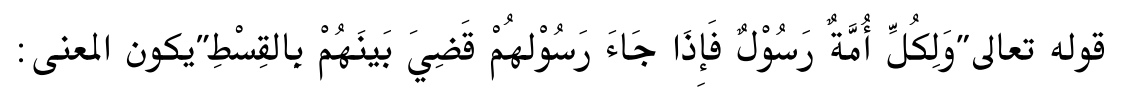

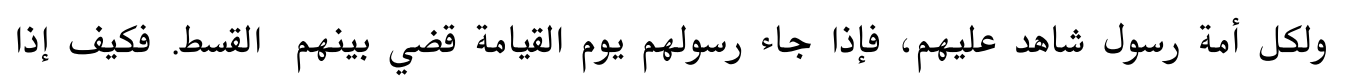
جئنا من كل أمة بشهيد وقال ابن عباس: تنكر الكفار غدا مجيء الرسل إليهم، فيؤتى بالرسول فيقول: قد أبلغتكم الرسالة، فحينئذ يقضى عليهم بالعذاب. دليله قوله: ويكون الرسول عليكم شهيدا. ويجوز أن يكون المعنى أنهم لا يعذبون في الدنيا حتى يرسل إليهم، فمن

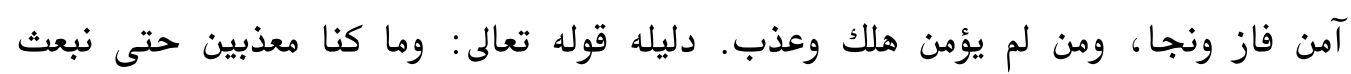
رسولا. والقسط: العدل. وهم لا يظلمون أي لا يعذبون بغير ذنب ولا يؤاخذون بغير حجة.

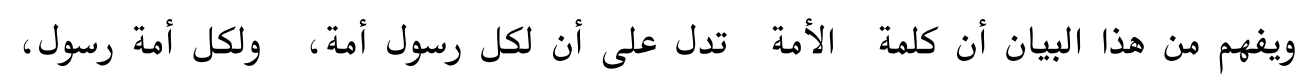

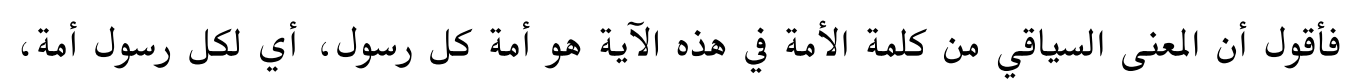
ولكل أمة رسول.

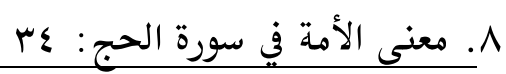

\begin{tabular}{|c|c|c|}
\hline السورة & لفظ الأمة & الرقم \\
\hline الحج: §ץ & 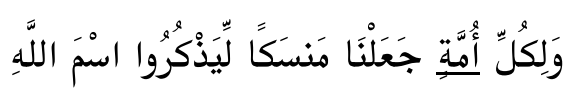 & $\wedge$ \\
\hline
\end{tabular}

إذا لاحظنا كلمة الأمة في هذه الآية إنها تملك معنى أساسيا هو: جماعة مؤمنة قد سلفت قبلكم. معنى الآية "ولكل أمة "أي: جماعة مؤمنة سلفت قبلكم "جعلنا منسكا" أي: مذبحا وهو موضع القربان، ليذكروا اسم اللّ على ما رزقهم من بهيمة الأنعام عند نحرها وذبحها، وسماها 'A Jamiy, Jurnal Bahasa dan Sastra Arab Volume 07, No. 1,Juni 2018 
بهيمة لأنها لا تتكلم، وقال "بهيمة الأنعام" وقيدها بالنعم، لأن من البهائم ما ليس من الأنعام

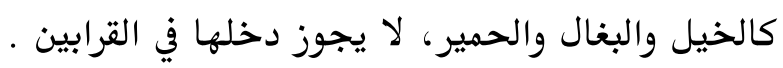

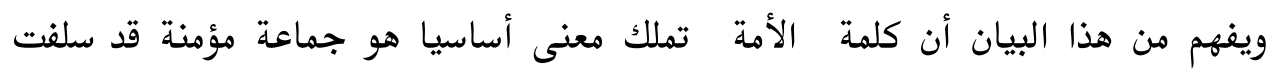
فأقول أن المعنى الأساسي من كلمة الأمة في هذه الآية هو جماعة مؤمنة سلفت من قبلنا.

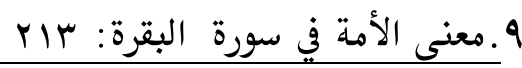

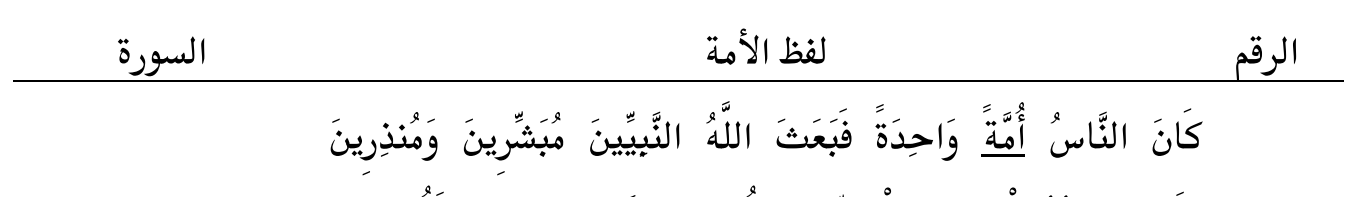

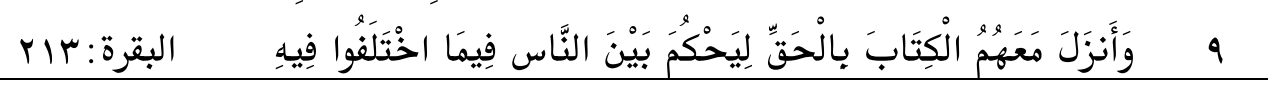

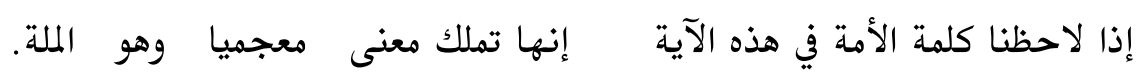

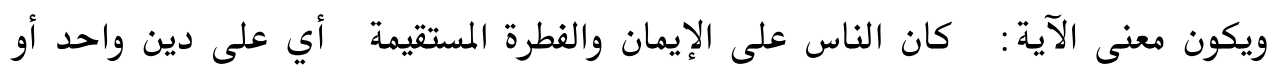

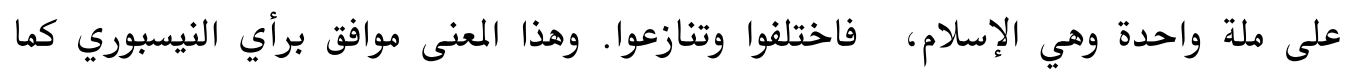
سار إليه في كتابه الوسيط في تفسير القرآن المجيد.

وهذه الآية تدل على أن آدم وذريته كانوا مسلمين وكانوا على دين ولنئ واحد ولئ وهو الإسلام.

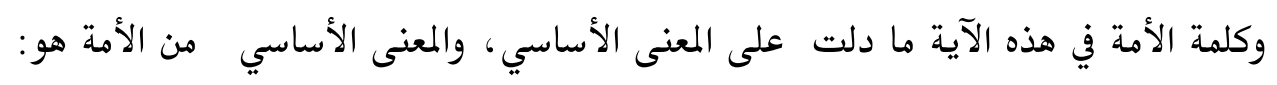

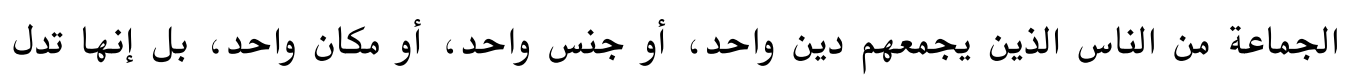

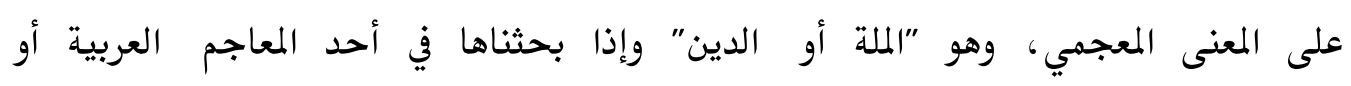
الإندونسية لوجدناها بمعنى دين أو ملة.

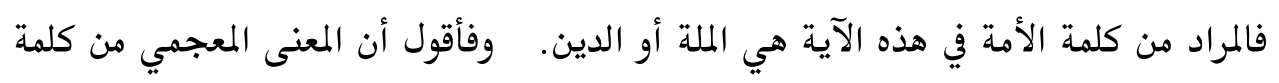

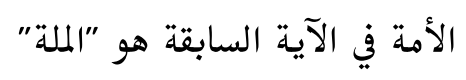

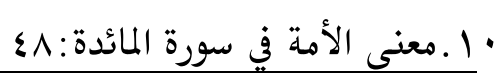

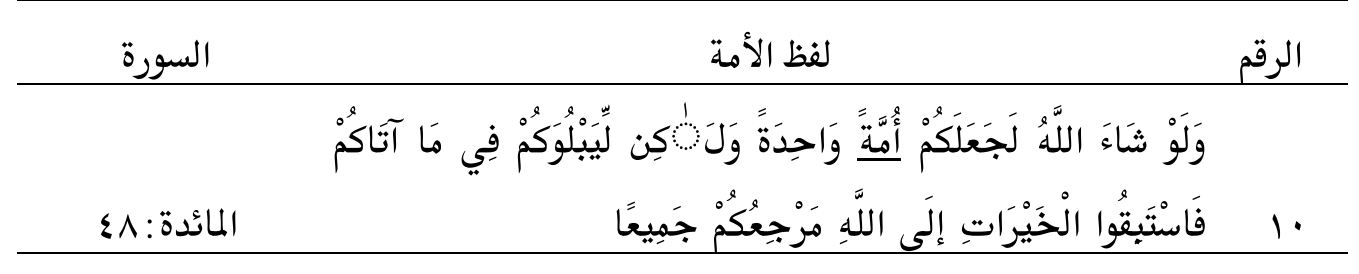
إذا لاحظنا كلمة الأمة في هذه الآية إنها تملك معنى معجميا هو الملة.

\section{'A Jamiy, Jurnal Bahasa dan Sastra Arab Volume 07, No. 1,Juni 2018}


هذه الآية خطاب للأمم الثلاثة : أمة موسى وأمة عيسى وأمةة محمد عليهم السلام، وللتوراة شريعة وللإنجيل شريعة وللفرقان شريعة والدين واحد وهو (التوحيد).

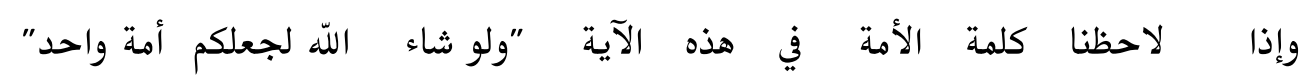
أي كأن الله يقول: ولو شاء اللّ لجعلكم على ملة واحدة وهي ملة التوحيد. فهم الباحث من

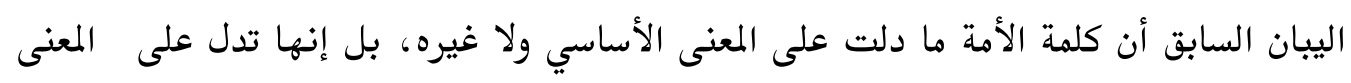

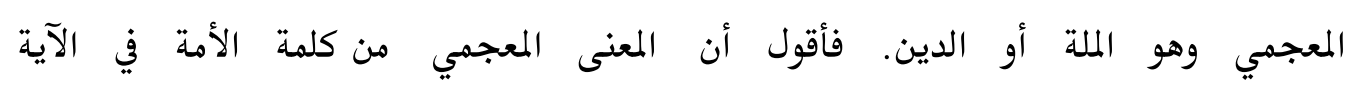
السابقة هو الملة أو الدين. ج. الخلاصة

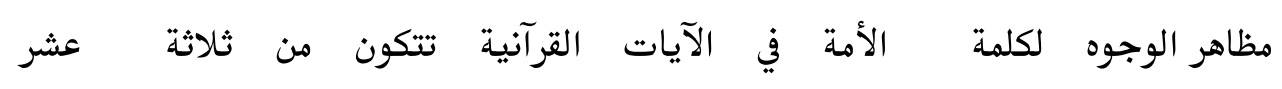

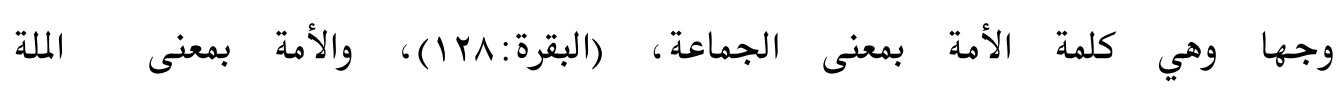

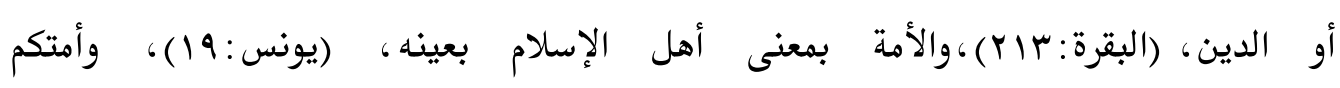

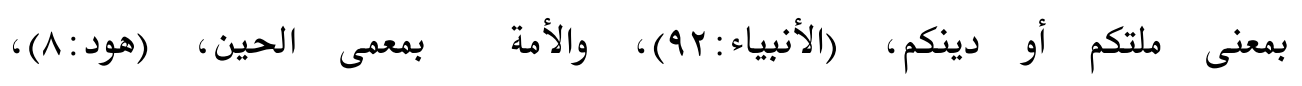

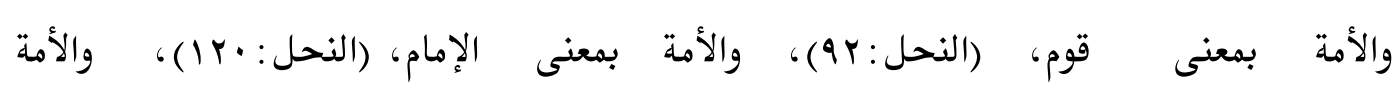

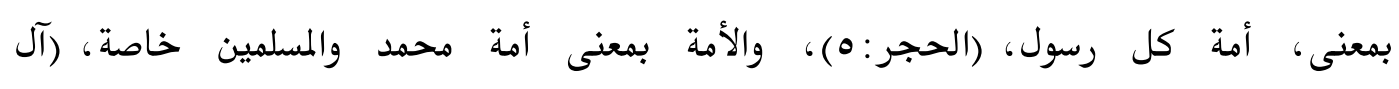

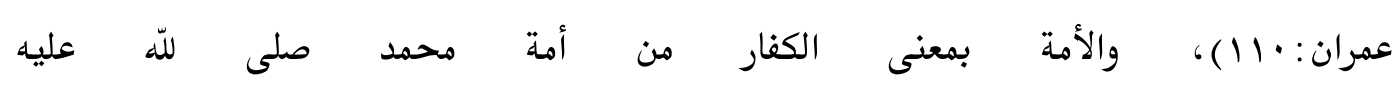

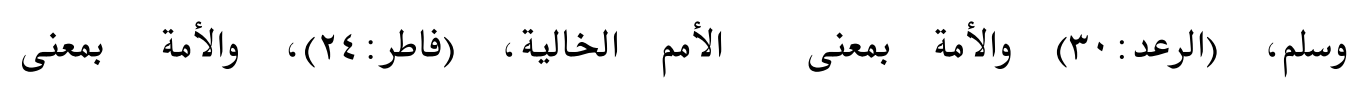

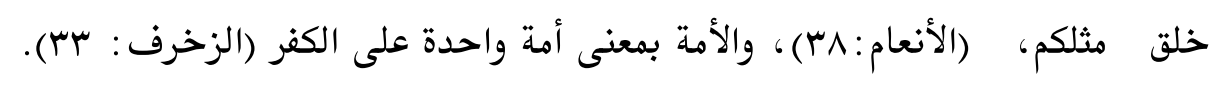

المراجع

القرآن الكريم

الإمام العلامة أبو الفضل جمال الدين محمد بن مكرم ابن منظور الأفرقي المصر

$$
\begin{aligned}
& \text { ي. } \\
& \text { لسان العرب. بيروت : دار صادر }
\end{aligned}
$$

العلامة عبد الرحمن جلال الدين السيوطي.المزهرفي علوم اللغةة، القاهرة: مكتبة دار التراث

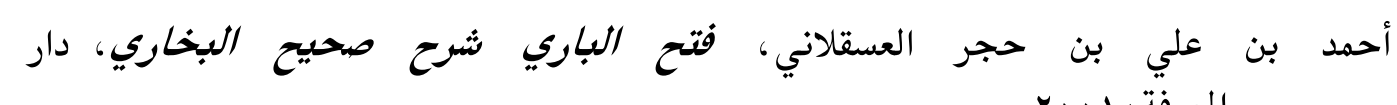

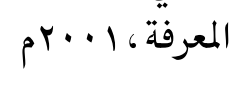

\section{'A Jamiy, Jurnal Bahasa dan Sastra Arab Volume 07, No. 1,Juni 2018}


عبد الرحمن بن الجوزي جمال الدين أبو الفرج. نزهة الأعين النواظر في علم الوجوه و النظائر.

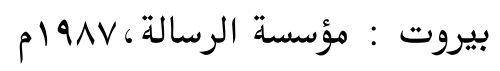

حاجي خليفة، كشف الظنون عن أسامي. الكتب والفنون. بيروت : دار إحياء التراث العربي p $191 \varepsilon$

الدكتور فريض عوض حيدر، علم الدلالة دراسة نظرية تطبيقية ، القاهرة،مكتبة النهضة المصرية، م 1999

الدكتور مختار، علم الدلالة ، الكويت، مكتبة دار العروبة، ب^وام

جلال الدين عبد الرحمن بن أبي بكر السيطي أبو الفضل.الاتقان في علوم

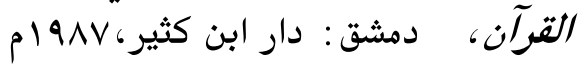

أحمد بن علي ابن حجر العسقلاني.تقريب التهذيب، بيروت: دار البشائر الإ

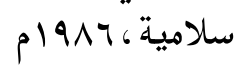

هارون بن موسى بن القارئ. الوجوه والنظائر في القرآن الكريم. وزارة الثقافية و الإعلام:دائرة

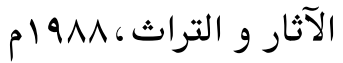

أرم غائم إسماعيل تكاي، المختصر في تعريف الاسم والوصف، والفعل، والخبر. العراق- هـ؟ اه أبو هلال العسكري. الوجوه والنظائر في القرآن الكريم. القاهرة:مكتبة الثقافية

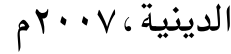

الدامغاني. قاموس القرآن أو إصلاح الوجوه والنظائر. بيروت: دار العلم للملا

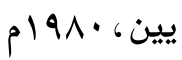

سليمان بن أحمد بن أيوب. أيوب القاسم الطبراني.مكتبة العلوم و الحكم، به9 م مصطفى الغلاييني.جامع الدروس العربية.صيدا، بيروت : المكتبة العصرية، ؛991م محمد علي الصابوني.صفوة التفسير. بيروت -لبنان.دار القرآن الكريم، 1911م

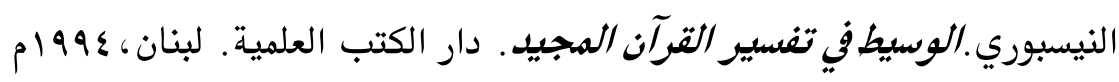

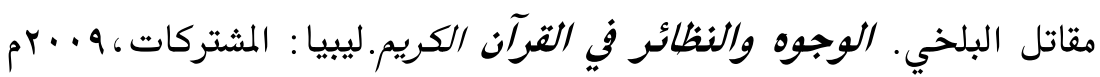

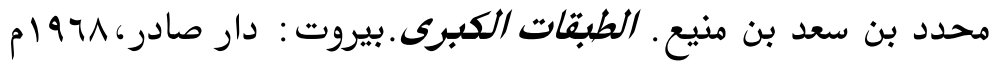

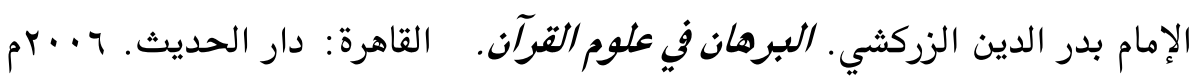

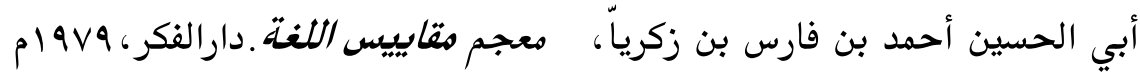

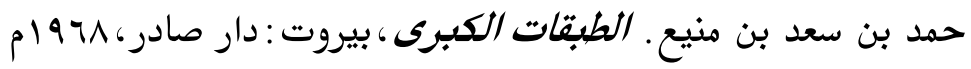

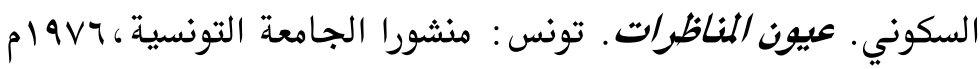

\section{'A Jamiy, Jurnal Bahasa dan Sastra Arab Volume 07, No. 1,Juni 2018}


$\{7$

$$
\begin{aligned}
& \text { الحكيم الترمذي. نوادر الأصول. بيروت: دار مصاد، هوAVم }
\end{aligned}
$$

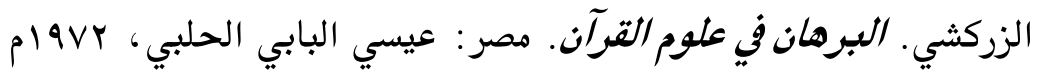

$$
\begin{aligned}
& \text { ابن فارس.مجمل اللغتة، بيروت : مؤسسة الرسالة، و9V9م }
\end{aligned}
$$

إسماعيل بن حماد الجوهري. الصحاح تاج اللغة.بيروت: دار العلم للملايين، p199

محمد بن الحسن بن دريد أبو بكر.جمهرة اللغتة. دار العلم للملايين. 9AVام ج ا 